\title{
History, rationale, and lessons learned: Thresholds of potential concern in Kruger National Park river adaptive management
}

\author{
Authors: \\ Craig A. McLoughlin ${ }^{1}$ \\ Andrew Deacon ${ }^{1}$ \\ Hendrik Sithole ${ }^{1}$ \\ Thomas Gyedu-Ababio ${ }^{2}$ \\ Affiliations: \\ ${ }^{1}$ South African National \\ Parks, Conservation \\ Services, Kruger National \\ Park, South Africa \\ ${ }^{2}$ South African National \\ Parks, Conservation \\ Management, Kruger \\ National Park, South Africa \\ Correspondence to: \\ Craig McLoughlin \\ Email: \\ Craig.McLoughlin@ \\ sanparks.org \\ Postal address: \\ Private Bag X402, Skukuza \\ 1350 , South Africa \\ Dates: \\ Received: 15 Apr. 2010 \\ Accepted: 02 Nov. 2010 \\ Published: 13 May 2011 \\ How to cite this article: \\ McLoughlin, C.A., Deacon, \\ A., Sithole, H. \& Gyedu- \\ Ababio, T., 2011, 'History, \\ rationale, and lessons \\ learned: Thresholds of \\ potential concern in \\ Kruger National Park river \\ adaptive management', \\ Koedoe 53(2), Art. \#996, \\ 27 pages. doi:10.4102/ \\ koedoe.v53i2.996
}

C 2011. The Authors. Licensee: OpenJournals Publishing. This work is licensed under the Creative Commons Attribution License.
The Kruger National Park's (KNP) adopted system of management, called Strategic Adaptive Management (SAM), originated during the Kruger National Park Rivers Research Programme (KNPRRP) of the 1990s. An important concept in SAM is the thresholds of potential concern (TPCs), representing end-points in a continuum of change. TPCs within the KNP SAM system guide management if or when reached, 'red-flagging' possible negative biodiversity impacts and catalysing consideration of management options. TPC-related monitoring generates the strategic information for ongoing evaluation, learning and adaptation within SAM. PostKNPRRP, although river flow and water quality TPCs have been implemented partly, those designed to detect undesirable changes in biodiversity have not been implemented, until recently. This paper describes the history, rationale, application and ongoing developments associated with the KNP river TPCs over the last decade, providing some key lessons for organisations utilising SAM. The paper concludes with an overview of new thinking and future directions envisaged for the KNP river TPCs, as part of the KNP SAM system.

Conservation implications: This paper documents important concepts of strategic adaptive management associated with the KNP river systems. Understanding, related to the rationale and justification for use and development or refinement of the thresholds of potential concern, lays an important foundation for ongoing work in managing these rivers adaptively.

\section{Introduction}

The paradigm shift in ecology from 'balance' to 'flux' of nature embraces notions about ecological systems as complex and dynamic, rather than homogeneous, linear systems (Pickett, Parker \& Fiedler 1992). Furthermore, change in conservation focus, from species to explicit ecosystem management, emphasises spatial and temporal change or heterogeneity (Rogers \& Bestbier 1997; Rogers 2003). With trends leaning towards biodiversity management at the ecosystem level (Poff et al. 1997) and a requirement for alternate methods to manage complexity in heterogeneous systems (Pickett, Cadenasso \& Benning 2003; Biggs \& Rogers 2003), it became opportune to instigate adaptive management processes for rivers in and around the Kruger National Park (KNP). This was fuelled by concerns about the deteriorating biophysical conditions of the KNP's aquatic and riparian ecosystems, due to upstream influences, for example, water abstractions, impoundments and pollution (Breen et al. 2000).

The Kruger National Park Rivers Research Programme (KNPRRP) was initiated towards the late 1980s to further river conservation efforts (Breen et al. 2000). A major thrust was the development of capacity to predict impacts of upstream influences on the biophysical condition of the rivers, for mitigation purposes. Breen et al. (2000), Rogers and Biggs (1999) and Rogers and O'Keeffe (2003) provide comprehensive reviews of this approximately 10-year multidisciplinary research programme, ultimately leading to the adoption of a strategic adaptive management system for KNP river management. The major challenges to scientists during the KNPRRP era included a need to (1) develop and describe a common understanding of the heterogeneity and dynamics of the KNP's river systems and then (2) to articulate this understanding to management within a strategic framework (Rogers \& Biggs 1999).

\section{Heterogeneity and the KNP river systems}

The first (1988-1993) and second (1994-1996) phases of the KNPRRP provided a multi-disciplinary, scaled understanding and predictive base for better decision making involving the KNP's river systems. This was important because causal links between catchment processes (land-use, water abstractions and sediment production) and downstream biotic responses were previously fraught with problems of scale and inter-disciplinarity (Rogers 1997). Spatial-temporal heterogeneity in 
the physical template of the river landscape, encompassing a highly variable flow regime and geology, governing patterns of sediment erosion, transportation and deposition, were key concepts. The formation of a diverse set of both alluvial- and bedrock-controlled geomorphic features within the river landscape leads to a diversity of habitat types (Van Niekerk, Heritage \& Moon 1995; Heritage, Van Niekerk \& Moon 1999), and biota that respond to these (e.g. Van Coller, Rogers \& Heritage 1997; Russell 1997; Van Coller, Rogers \& Heritage 2000; Rogers \& O’Keeffe 2003). Knowledge of this type became the basis for predicting biodiversity responses to changing catchment conditions that affect and influence the river systems (Rogers \& O'Keeffe 2003).

\section{A strategic adaptive framework for managing KNP rivers}

Managing complex systems characterised by uncertainty requires an adaptive, learning-by-doing approach (Rogers 2003; Stankey, Clark \& Bormann 2005, see editorial by Roux \& Foxcroft 2011). Indeed, a key principle is that appropriate management actions should be implemented, even if based on imperfect knowledge, because complete understanding is never attainable realistically (Rogers 2003). Furthermore, management actions present potential learning opportunities, feeding back more reliable information to improve decision making (Rogers \& Biggs 1999). The strategic adaptive management (SAM) framework pioneered during the final phase (1997-1999) of the KNPRRP requires the articulation of a vision, a hierarchy of objectives, ultimately leading to specific end-points to guide management (see Rogers \& Bestbier 1997). The development of purposeful monitoring programmes to audit against these end-points is important (see Rogers \& Bestbier 1997; Rogers and O'Keeffe 2003). The end-points, known as thresholds of potential concern (TPCs) within SAM, are upper and lower levels of acceptable change that when exceeded, set in motion a process of investigation as to the reasons why the TPC was exceeded (Biggs \& Rogers 2003). Possible management action, or revision of the actual TPC, is then considered (Biggs \& Rogers 2003).

The first TPCs developed for the KNP rivers (from KNPRRP) were linked to a vision of maintaining biodiversity in all its natural facets and fluxes, via a hierarchy of objectives (see Rogers \& Bestbier 1997; Rogers \& Biggs 1999 for a detailed account). These TPCs addressed issues of river flow, water quality (physical-chemical guidelines), and sedimentation (geomorphic indictors). In addition, TPCs were developed to test biotic response to deteriorating river flows and unnatural increases in sedimentation (fish, macro-invertebrates and riparian vegetation indicators), and alterations to the flooding regime (riparian vegetation indicators), resulting from upstream human influences. Although identified as a potential problem, a TPC for reed cover was not completed because of capacity issues. TPCs were also developed for alien vegetation invasions (Foxcroft 2009), relating invasions to the introduction, spread and increase in abundance of alien species.

\section{Lags in implementation of SAM}

Until recently, however, only the river flow and water quality TPCs had been implemented sufficiently within the KNP river SAM system, post-KNPRRP. Many factors contributed to this outcome. Within the KNP, a full implementation of the monitoring and reporting systems did not get off the ground. This diminished the capacity to feed back information into evaluation and learning, critical within any adaptive management system. In the wider catchment context, lags in implementation of environmental flow requirements had been (and remain) a major setback for SAM. This has diminished motivation for testing the biophysical response components. KNP influences outside of the park have, however, been partially successful in improving river flows.

In this paper, we discuss the river TPCs (operational and biodiversity-related) within the KNP, involving pertinent monitoring, reporting and feedback processes. We focus firstly on the history and rationale for the specific TPCs, including application and ongoing developments. We then highlight key learning opportunities achieved so far, postKNPRRP, pertinent to other organisations utilising SAM. We conclude by providing an overview of new thinking and future directions envisaged for the KNP river TPCs.

\section{The operational thresholds of potential concern TPCs for river flow Rationale}

Under the South African National Water Act (Act 36 of 1998), the quantity and quality of water required to protect the ecological functions on which humans depend (defined as the Ecological Reserve) must be determined and maintained in natural water resources (O'Keeffe \& Rogers 2003). Over the past decade, the KNP has monitored environmental flows within all major rivers according to in-stream flow requirements (IFRs; the minimum flow required to sustain ecologically healthy rivers), determined during the 1990s using the 'Building-Block' methodology (see King \& Louw 1998) (see Table 1). Although the IFRs were well researched, they are considered minimum flows required to avoid unacceptable biodiversity loss in the rivers. In addition, unnaturally high flows are of concern, leading to biodiversity impacts too. For example, the practice of releasing high water volumes during low flow periods may provide breeding cues for fish at the wrong time of the year (Russell 1997).

For a full treatise, a number of sources provide detailed information on methods used in the development of IFRs for each of the KNP rivers: Crocodile River - CSIR (2002); Olifants, Letaba and Shingwedzi Rivers - DWAF (1991); Sabie River - Tharme (1997) and Luvuvhu River - Louw and O’Keeffe (1999).

\section{Application, refinements and assessment post-KNPRRP}

Although high flows are incorporated within the IFR tables, only the low flows under the maintenance and the drought scenarios have been utilised as TPCs (see Table 1). There 
TABLE 1: In-stream flow requirements, as determined for the Kruger National Park rivers using the 'Building Block' methodology.

\begin{tabular}{|c|c|c|c|c|c|c|c|c|c|c|c|c|c|c|}
\hline Virgin MAR $1968 \times 10^{6} \mathrm{~m}^{3}$ & Oct. & Nov. & Dec. & Jan. & Feb. & Mar. & Apr. & May & June & July & Aug. & Sept. & Total & $\%$ of MAR \\
\hline \multicolumn{15}{|l|}{ IFR maintenance low-flows } \\
\hline Discharge $\left(\mathrm{m}^{3} / \mathrm{s}\right)$ & 7.00 & 10.30 & 11.80 & 16.00 & 20.00 & 17.00 & 12.90 & 11.00 & 9.40 & 8.20 & 7.40 & 7.00 & - & - \\
\hline Max depth (m) & 0.46 & 0.53 & 0.56 & 0.63 & 0.69 & 0.65 & 0.58 & 0.55 & 0.51 & 0.48 & 0.47 & 0.46 & - & - \\
\hline Monthly volume $\left(10^{6} \mathrm{~m}^{3}\right)$ & 18.75 & 26.70 & 31.60 & 42.85 & 48.38 & 45.53 & 33.44 & 29.46 & 24.36 & 21.96 & 19.80 & 18.14 & 361.00 & 18.30 \\
\hline \multicolumn{15}{|c|}{ IRF maintenance floods/freshets } \\
\hline Discharge $\left(\mathrm{m}^{3} / \mathrm{s}\right)$ & 14.00 & 50.00 & 30.00 & 50.00 & 150.00 & 50.00 & 26.00 & - & - & - & - & - & - & - \\
\hline Max depth $(\mathrm{m})$ & 0.60 & 1.00 & 0.81 & 1.00 & 1.55 & 1.00 & 0.77 & - & - & - & - & - & - & - \\
\hline Duration (days) & 3 & 5 & 4 & 5 & 7 & 5 & 4 & - & - & - & - & - & - & - \\
\hline Return period (year) & 1 & 1 & 1 & 1 & 1 & 1 & 1 & - & - & - & - & - & - & - \\
\hline Monthly volume $\left(10^{6} \mathrm{~m}^{3}\right)$ & 1.09 & 8.13 & 6.60 & 6.96 & 32.80 & 6.76 & 2.38 & - & - & - & - & - & 64.70 & 3.30 \\
\hline \multicolumn{15}{|l|}{ IFR drought low-flows } \\
\hline Discharge $\left(\mathrm{m}^{3} / \mathrm{s}\right)$ & 2.00 & 2.80 & 3.10 & 4.10 & 5.00 & 4.30 & 3.30 & 2.90 & 2.50 & 2.20 & 2.10 & 2.00 & - & - \\
\hline Max depth (m) & 0.28 & 0.32 & 0.33 & 0.37 & 0.40 & 0.37 & 0.34 & 0.32 & 0.30 & 0.29 & 0.28 & 0.28 & - & - \\
\hline Monthly volume $\left(10^{6} \mathrm{~m}^{3}\right)$ & 7.36 & 7.26 & 8.30 & 10.98 & 12.10 & 11.52 & 8.55 & 7.77 & 6.48 & 5.89 & 5.62 & 5.18 & 95.00 & 4.80 \\
\hline \multicolumn{15}{|l|}{ IFR drought floods/freshets } \\
\hline Max depth (m) & 0.36 & 0.53 & 0.69 & 0.53 & 1.00 & 0.53 & 0.43 & - & - & - & - & - & - & - \\
\hline Duration (days) & 2 & 3 & 4 & 3 & 5 & 3 & 2 & - & - & - & - & - & - & - \\
\hline Return period (year) & 1 & 1 & 1 & 1 & 1 & 1 & 1 & - & - & - & - & - & - & - \\
\hline Monthly volume $\left(10^{6} \mathrm{~m}^{3}\right)$ & 0.24 & 1.12 & 3.07 & 0.92 & 9.21 & 0.89 & 0.33 & - & - & - & - & - & 15.80 & 8.00 \\
\hline
\end{tabular}

The Olifants River is used as an example.

IFR, in-stream flow requirements; MAR, mean annual run-off.

has been frequent tabling (and un-tabling) of river flow TPCs, using the IFR levels as lower thresholds to river flow. Notably, the KNP river management have experienced many challenges associated with actual compliance with these IFRs (see Figure 1).

The implementation of the river flow TPCs over the past decade has provided key opportunities to improve the system within the SAM framework. Firstly, reporting of river flow conditions to scientists and managers was considered inadequate for making informed assessments to guide decision making. For example, information for comparing river flow situations between time periods was lacking. Furthermore, feedback about management action outside of the KNP was not made explicitly available to the relevant people, therefore making it difficult to assess and learn from past actions. In addition, river flow reporting relied heavily on the motivation and discretion of the river technician at that time, making this component highly vulnerable.

Changes to the river flow TPC system therefore occurred in 2008, and included (1) automation of TPC auditing procedures via the introduction of a simple Excel spreadsheet program, where mean daily discharge values are entered; the program indicates if or when river flow TPCs are exceeded, for tabling at the bi-monthly KNPConservation Management Committee meeting where management actions are considered, (2) the summarising of statistics to provide information on trends in river flow and (3) the introduction of a management log to record relevant management information, for later use in feedbacks (see Table 2).

Secondly, the benchmarks against which to measure river flows (i.e. IFRs) have, at least conceptually, become increasingly difficult to use. This is because (1) determining when the maintenance or drought IFRs should be used is intricate, as rainfall influences cannot be predicted easily, (2) the static nature of the IFRs (within months, between years) does not mimic natural flow variability realistically and (3) there are high demands for water in the catchments. Some catchments are under severe water demand stress (e.g. the Crocodile River), with increasing pressure to allocate scarce water resources before the Ecological Reserve requirements are met. In essence, it has become difficult for the KNP to demand more water without adequate benchmarks against which to measure.

Therefore, in 2009, changes were proposed to improve the river flow TPC process. This included recalibrating the river flow TPCs, that is, selecting a level between the maintenance and drought IFRs that could be used to initiate management action realistically, considering water demand in the catchments. Subsequently however, major rethinking resulted in a decision to discontinue the TPC tabling process for river flow. The main reason was that the bi-monthly timeframe for TPC tabling at the KNP Conservation Management Committee meeting was inadequate to catalyse management action in time, prior to undesirable river flow conditions occurring. Thus, during a meeting held in Skukuza (River Flow workshop), KNP scientists and managers agreed to start strengthening the more pertinent rapid systems for dealing with deteriorating river flows.

Since July 2009, a 'Rapid Response System' has been in place, incorporating increasing levels of concern from management if or when river flows reach various critical levels relative to the IFRs. The spreadsheet program (described above) has been modified to indicate (with discharge data inputs) when river flows fall within different 'worry zones'. This is so that pertinent action, by the individuals in the relevant management level, can take place in time, for example, by contacting the water resource manager to make releases from dams (McLoughlin 2009). For evaluation purposes, feedback is provided to the KNP Conservation Management 

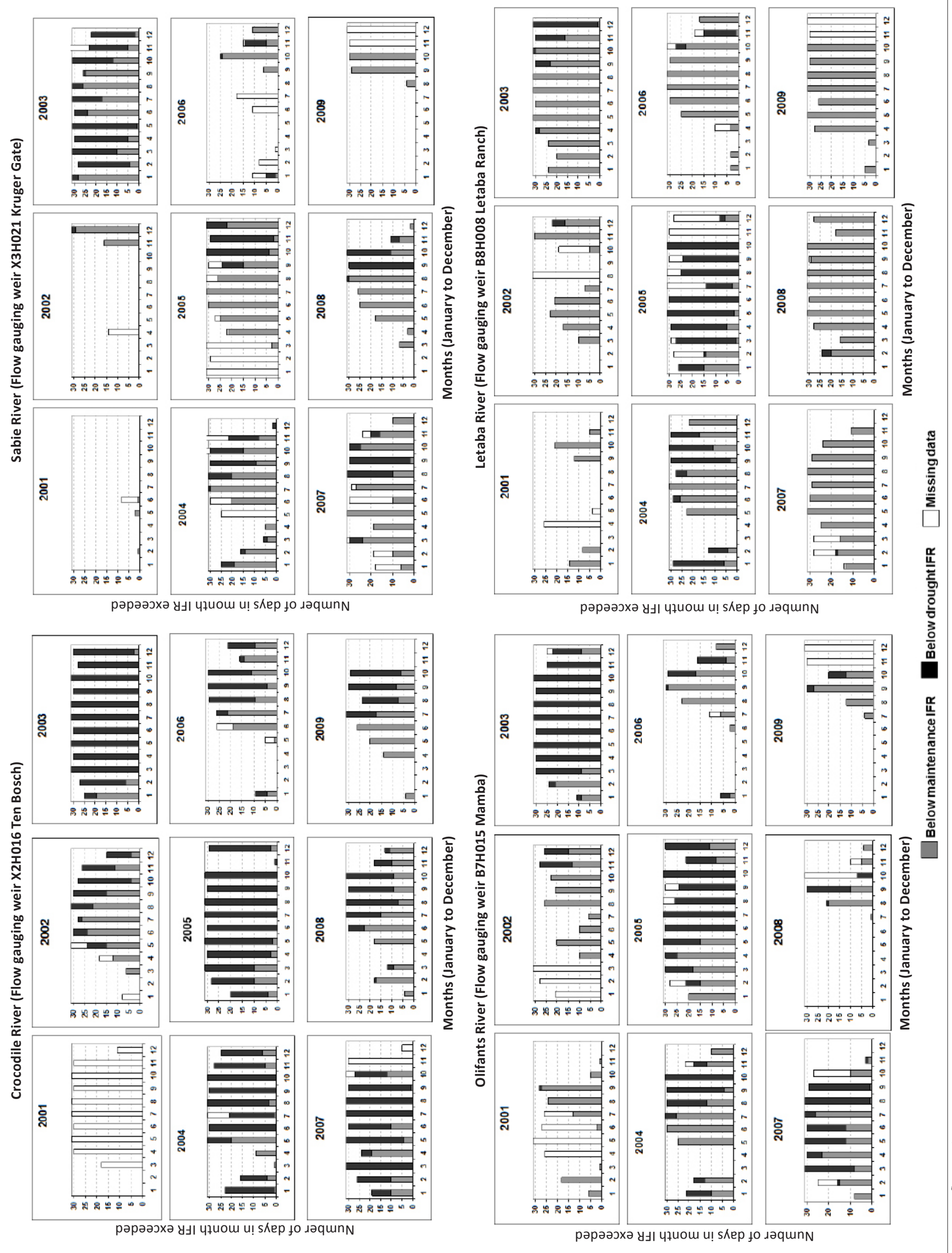
TABLE 2 : The Kruger National Park (KNP) management log, used within the KNP Strategic Adaptive Management system for rivers.

\begin{tabular}{|c|c|c|}
\hline Management problem & Management options & Management action \\
\hline $\begin{array}{l}27 \text { August } 2010 \\
\text { Olifants River flows at } 11 \\
\text { cumec which is in the Response } \\
\text { Level1. }\end{array}$ & $\begin{array}{l}\text { 1. Contact Lepelle/DWA } \\
\text { 2. Inform River manager }\end{array}$ & Contact Lepelle Northern Water \\
\hline $\begin{array}{l}19 \text { August } 2010 \\
\text { Sabie River flows below old IFR } \\
\text { of } 4.5 \text { cumec and in the Medium } \\
\text { worry zone }\end{array}$ & $\begin{array}{l}\text { 1. Contact DWA } \\
\text { 2. Inform River manager }\end{array}$ & $\begin{array}{l}\text { Contact B. Jackson, Inkomati CMA } \\
\text { Contact Deon Joubert at DWA Hydro } \\
\text { to find out about a sudden drop in flow } \\
\text { at the Kurger Gate flow gauging weir }\end{array}$ \\
\hline
\end{tabular}

Result

According to Lepelle they are currently

discharging 20 cumec but they calculate the outlet according to a sluice gate opening and not a flow gauging instrument. They will look into it.

Brian informed that release from Inyaka Dam was done a week ago and the situation will be monitored. Deon informed that a correction was made to the flow gauging equipment at Kruger Gate on 12 August by the new technician and thus there was a drop of 2 cumecs since.

\begin{tabular}{|c|c|c|}
\hline 16 August 2010 & 1. Contact DWA & Informed KNP Management \\
\hline $\begin{array}{l}\text { Crocodile River flow decrease } \\
\text { drastically, flowing at } 2.5 \text { cumec } \\
\text { for a few hours. DIFR }=2 \text { cumec }\end{array}$ & 2. Inform River manager & \\
\hline
\end{tabular}

\section{Contact DWA}

2. Inform River manager

Sabie River flows below old IFR in

the Medium worry zone

\section{July 2010 \\ Crocodile River flow below old IFR in the Medium worry zone \\ June 2010 \\ Crocodile River flowed below old}

IFR for a few days

June 2010

Letaba River flowed close to old

IFR but still well above new Reserve

This summarises the main activity associated with the 'Rapid Response System' for river flows.

IFR, in-stream flow requirements; DIFR, drought in-stream flow requirements.

CMA, catchment management agency; DWA, Department of Water Affairs; DWAF, Department of Water Affairs and Forestry.

Committee bi-monthly for assessment about the effectiveness of the 'Rapid Response System'. This includes a graphic depiction of daily river flow per river, per month, indicating if/when management actions have been taken (see Figure 2 [a]), as recorded in the management log. In addition, summary statistics about flows are still presented (see Figure $2[\mathrm{~b}]$ ), providing information about management performance over a specified time period. Initial feedback from managers and scientists suggests that this system does provide better information formats for interpretation and assessment, for improved decision making.

\section{TPCs for water quality}

\section{Rationale}

According to the KNP Water Provision policy (KNP 1989), the 'abuse' of perennial rivers in the KNP in the form of pollution and abstraction commenced in the 1920s with the advent of industrial and agricultural development in the lowveld and adjoining areas. Silting of rivers had also increased from the mid-1940s. The stringent quality requirements set by the Department of Water Affairs and Forestry (DWAF) primarily for drinking water have been adopted by the KNP as TPCs (Table 3). These were then seen as stringent enough for ecosystem requirements as well (however, this is currently not the case). Notably, these TPCs (see Rogers \& Bestbier 1997) had been implemented within the KNP SAM system and integrated with the national water quality monitoring programme under the auspices of the national DWAF (now Department of Water Affairs - DWA). The DWA supply and maintain the equipment and consumables, analyse the samples and maintain a national database.
The present water quality guideline for ecosystem maintenance is incomplete. As an interim measure it was suggested by representatives of the Institute for Water Quality Studies, the Freshwater Research Unit of the University of Cape Town and the Institute for Water Research at Rhodes University to use a combination of standards until more information becomes available (Table 3). The sources for standards used at different sampling sites along the major KNP rivers include: Crocodile, Letaba and Luvuvhu Rivers - DWAF (1996), Rogers and Bestbier (1997); Sabie River - Rogers and Bestbier (1997). A combination of the South African Water Quality Guideline for domestic use, the South African Water Quality Guideline for aquatic ecosystems (DWAF 1996) and those proposed by Kühn (1991) are used for the Olifants River.

\section{Application, refinements and assessment post-KNPRRP}

It was realised that the isolated efforts of KNP towards the management of water quality of rivers that run through the park would not be enough to ensure the achievement of its objectives, since the impacts on the water quality originate upstream before entering the KNP. The KNP, therefore, decided to spearhead activities associated with integrated water resource management (IWRM) in relevant catchments that involve the park. Stakeholder involvement became a priority, leading to the birth of the Catchment Forums. Stakeholder involvement includes a number of activities: awareness creation and specialist inputs on water related issues - monitoring of the quality and quantity of water, water- related research, information sharing and knowledge transfer. The Crocodile River Forum and related activities is 


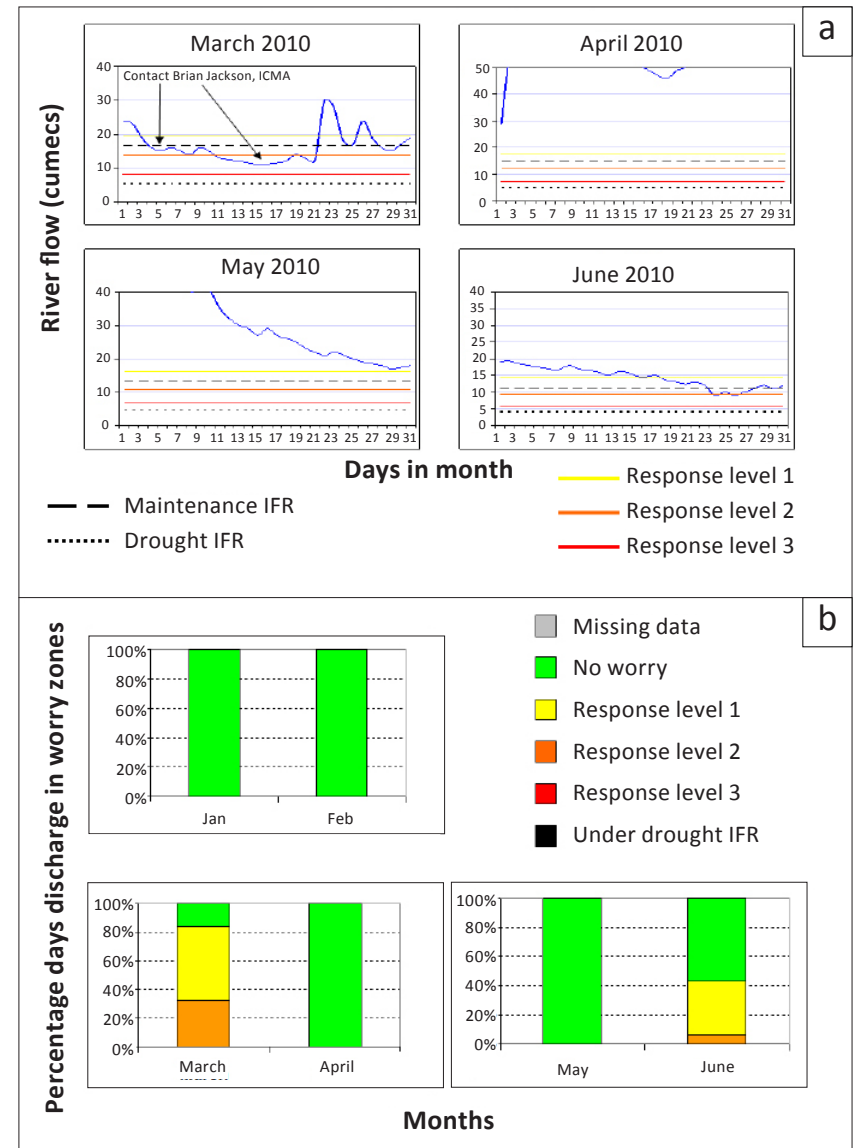

An example showing data from the Crocodile River, using the Tenbosch gauging station. IFR, in-stream flow requirements; cumecs, cubic meters per second.

FIGURE 2: The new information format for river flows within the Kruger National Park, indicating Rapid Response (worry levels) zones.

a good example of this process.

Water quality monitoring networks cannot be static entities, but require ongoing change, for example, objectives, technology and data users (Sanders \& Ward 1993). In 2000, the technical committee of the Crocodile River Forum divided the catchment into four management units for the purpose of water quality monitoring, consisting of the Upper Kwena, Nelspruit, Kaap and the Kruger National Park (see Box 1[a]) management units. Water Quality Objectives (WQOs) were then developed, based on the newly developed model for Resource Quality Objectives (RQO). This incorporated the DWA Target Water Quality Range (DWAF 1996) and the
Desktop River Classifications. The requirements of water users, historical water quality trends and existing standards (including KNP TPCs) were considered. Hence, a common set of WQOs for the entire sub-catchment is being used as the guideline for monitoring of water quality (see Box 1[b]), and relevant information is fed back at the forum meetings (see Box 1[c] - for example, conductivity measurements).

Whenever there are non-conformances to the agreed objectives, the sources of non-compliance are investigated and action is taken. This has contributed immensely to improving the management of water quality in the Crocodile River catchment. Sewage pollution remains a problem however, but improvements are occurring via actions of the Crocodile River Catchment Forum.

\section{The biodiversity thresholds of potential concern}

The suite of river TPCs within the KNP SAM system incorporates a number of biophysical components as well, designed to test effectiveness of the environmental flows and water quality entering the KNP river systems. These include (1) the in-stream TPCs - making use of the National River Health Programme monitoring tools for habitat, fish and macro-invertebrates and (2) the riparian TPCs - for sedimentation, loss of bedrock influence and vegetation changes.

\section{In-stream TPCs}

The River Health Programme (RHP) was designed in the early 1990s as a nationwide monitoring system to assess river health (see DWAF 1998) and is a component of the National Aquatic Ecosystem Health Monitoring Programme (DWAF 2008a). The KNP (and South African National Parks) has been involved with the RHP from the onset, and is actively involved with the development of methodologies, and implementation of these.

The aim of the RHP is to generate information for the national state-of-the-rivers reporting. As such, it involves the rapid monitoring of a comparatively large number of sites distributed over all catchments of concern (Kleynhans et al. 2005). The RHP has various monitoring tools to generate

TABLE 3: Guidelines used to assess thresholds of potential concern for water quality, associated with the major Kruger National Park rivers.

\begin{tabular}{|c|c|c|c|c|c|}
\hline Element & Crocodile River & Sabie River & Olifants River & Letaba River & Luvuvhu River \\
\hline $\mathrm{pH}$ & $6.50-8.50$ & $6.50-8.10$ & $6.50-9.00$ & $6.50-8.50$ & $6.50-8.50$ \\
\hline Nitrate (mg/l) & 6.00 & 0.20 & 6.00 & 6.00 & 6.00 \\
\hline Ammonium ( $\mu \mathrm{g} / \mathrm{l})$ & 15.00 & 15.00 & 10.00 & 15.00 & 15.00 \\
\hline Phosphorus (mg/l) & 0.01 & 0.02 & 0.10 & 0.02 & 0.10 \\
\hline Sodium (mg/l) & 100.00 & 11.00 & 100.00 & 100.00 & 100.00 \\
\hline Chloride (mg/l) & 100.00 & 17.00 & 100.00 & 150.00 & 100.00 \\
\hline Fluoride (mg/l) & 0.20 & 0.20 & 1.00 & 1.50 & 2.00 \\
\hline Conductivity $(\mathrm{mS} / \mathrm{m})$ & 70.00 & 16.00 & 120.00 & 70.00 & 80.00 \\
\hline Calcium (mg/l) & 32.00 & 9.00 & 32.00 & 32.00 & 32.00 \\
\hline Magnesium (mg/l) & 30.00 & 6.00 & 30.00 & 30.00 & 30.00 \\
\hline Sulphate (mg/l) & 200.00 & 11.00 & 250.00 & 200.00 & 200.00 \\
\hline TDS (mg/l) & 450.00 & 104.00 & 800.00 & 450.00 & 520.00 \\
\hline
\end{tabular}




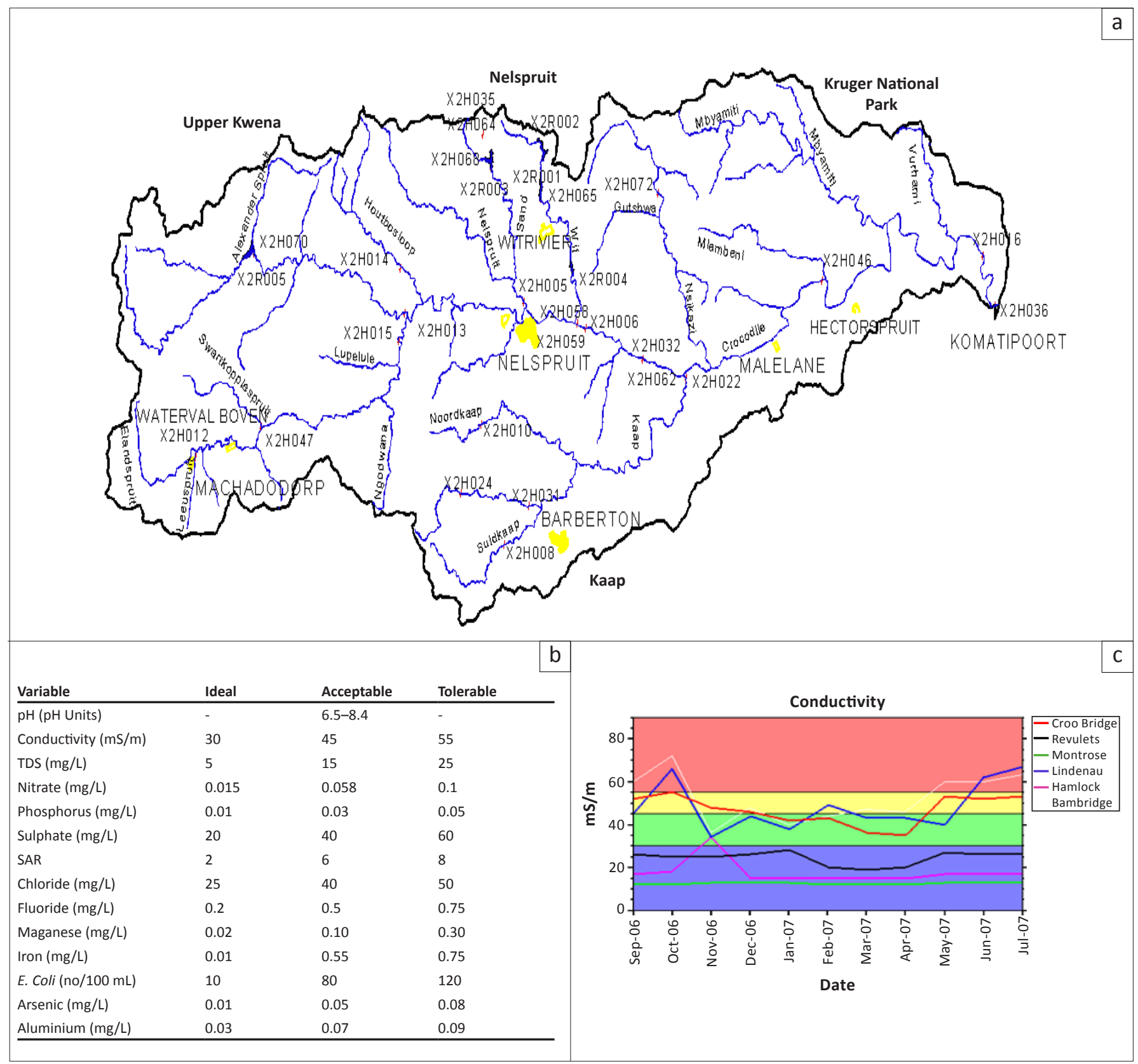

BOX 1: (a), (b), (c): Water quality management units, guidelines and feedback system currently employed by the Crocodile River Forum.

relevant information that can be used to compile in-stream TPCs. The two sections below describe the history and development of the fish- and macro-invertebrate-related monitoring and reporting within the KNP, ultimately becoming an important contributor to the RHP.

\section{TPCs using fish indicators}

\section{Rationale}

Broad surveys and ad hoc monitoring of fish started in the early 1950s, but from the 1960s more detailed and systematic surveys were undertaken. After surveys of all the perennial rivers were completed, Pienaar (1961) published a list of fish species, and a guidebook was produced in 1969. Riverine monitoring only started in earnest when the KNPRRP was launched in 1987. Russell (1997) presented results from a study conducted from 1987 to 1989, and Weeks et al. (1996) did extensive surveys for the Sabie River. However, a structured monitoring programme was only initiated from the early 1990s when a full-time river scientist was employed in the KNP.

Fish are considered suitable indicators for monitoring the aquatic system because as consumers they integrate the effects of detrimental environmental changes, being relatively high up in the aquatic food chain (Hellawell 1978). Fish have been used as indicators of environmental conditions on the basis of individuals, populations and indicator species. Motivation for the monitoring of fish assemblages in the KNP rivers stems from concerns regarding the effects that catchment development have on the quantity and quality of water affecting the integrity of aquatic biota. It was envisaged that a monitoring programme could provide a means of detecting incipient change in the diversity of fish assemblages. This 
would act as an early warning system of deterioration in the aquatic environment, and signify a need for management response.

The first fish-related TPCs were developed during the KNPRRP (see Rogers \& Bestbier 1997). However, after a $\mathrm{PhD}$ study on monitoring and fish assemblages in KNP (Russell 1997), and a Water Research Commission-associated workshop (Fish TPCs January 2000), a decision was made to concentrate on the Fish Assemblage Integrity Index (FAII) (see Kleynhans 1999). The FAII embraces sensitivity, frequency of occurrence and percentage anomalies, and has resulted in the upgraded TPCs of identified criteria for fish in the KNP (see Table 4).

\section{Application, refinements and assessment post-KNPRRP}

The Fish Rapid Assessment Index (FRAI) replaced the FAII and formed the core of the fish TPC process (see Kleynhans 2007). The FRAI is based on the categorisation of the fish community according to an intolerance rating. This includes trophic preference and specialisation, and requirement for flowing water during different life-stages and habitats with unmodified water quality. Results from the FRAI are expressed numerically and as a ratio of observed conditions versus conditions that would have been expected in the absence of human impacts. The numerical scores indicate the direction of change when measured against an agreed upon, desired ecological category.

There has been ongoing assessment of the fish monitoring data using the FRAI, however, very few outcomes had been evaluated successfully within a TPC framework. The main reason was that outputs from the FRAI model are not refined enough to differentiate between habitat, river flows and water quality influences that were impacting fish. This is exacerbated by river systems being highly complex. Thus, implementing pertinent management response to the FRAI model outputs has proved difficult. Although the RHP can provide the necessary tools for development of fish TPCs, the following issues have been raised (TPC Workshop, Skukuza, 2007), (1) the RHP does not provide sufficient insight into cause-and-effect relationships, (2) species sensitivity to influences should be unpacked and then (3) TPCs for all rivers should be developed using these findings. Furthermore, 'red-flagging' (TPC tabling) too many concerns would cause the TPC process to lose impetus, that is, an overload of monitoring, reporting and managing would be impractical.

Hence, a new suite of detailed fish TPCs was generated, based on methods developed during the Ecological Reserve Determination Studies for the Letaba River (see DWAF 2006). It is important to note that specific fish species are chosen as indicators of change in the main drivers in the river system, for example, river flow and/or water quality, and should act as an early warning system when conditions begin to deteriorate. Testing of this approach was completed in 2008 using sites along the Olifants River (McLoughlin, Deacon \& Sithole 2009a). This effort led to the first official tabling of a fish TPC within the KNP's SAM system (McLoughlin et al. 2009a). It is notable that there are still gaps and shortcomings in the implementation of the KNP fish TPC system. This is, however, being addressed currently.

\section{TPCs using macro-invertebrate indicators}

\section{Rationale}

Gold mining along the upper Sabie River in the 1920s prompted the first environmental study (1933) in the KNP, related to invertebrates (Moore \& Chutter 1988). The study indicated that the river was impacted severely by the discharge of waste into the river, with virtually no small aquatic life present. The second study investigated the diversity of benthic invertebrates, and was completed along the Crocodile and Sabie Rivers in 1959 by the National Institute for Water Research. New species were discovered comprising the Ephemeroptera and Trichoptera families, with the Sabie River having more benthic invertebrate diversity than the Crocodile River (Moore \& Chutter 1988). A third study was conducted along the Crocodile, Sabie, Olifants, Letaba, Luvuvhu and Motale Rivers in 1985/1986 because of concerns about mining impacts (Moore \& Chutter 1988). The main objectives were to make monitoring recommendations for conservation purposes, based on the presence of benthic invertebrates. The Sabie and Luvuvhu Rivers had the lowest chemical concentrations; Sabie River had the highest invertebrate taxa diversity, followed by Luvuvhu, Mutale, Crocodile, Olifants and Letaba Rivers. Moore and Chutter (1988) recommended the implementation of a benthic invertebrate monitoring programme in the KNP rivers to provide warnings of insidious changes in the benthic invertebrates, therefore of a broader river health.

TABLE 4: The developed and more focused fish thresholds of potential concern (TPCS) for the Kruger National Park rivers.

\begin{tabular}{|c|c|c|}
\hline Group & Indicator & Proposed TPCs \\
\hline \multirow[t]{3}{*}{ In-stream fish } & $\begin{array}{l}\text { Distribution and occurrence of individual } \\
\text { species. }\end{array}$ & $\begin{array}{l}\text { 1. A decrease (>35\% decline in number of localities collected in different surveys) in the } \\
\text { distribution of an indigenous fish species that is permanently resident in a river and where } \\
\text { the reason for the decline is the consequence of man-induced changes in the aquatic } \\
\text { environment. }\end{array}$ \\
\hline & & $\begin{array}{l}\text { 2. An increase (>35\% increase in number of localities collected in different surveys) in the } \\
\text { distribution of permanently resident, indigenous fish species, where the reason for the } \\
\text { increase in the consequence of man-induced changes in the aquatic environment and where } \\
\text { the increased distribution of said species threatens the conservation status of any other } \\
\text { species. }\end{array}$ \\
\hline & & 3. The establishment or increase in the distribution of an alien fish species. \\
\hline $\begin{array}{l}\text { Fish Assemblage Integrity Index } \\
\text { (FAII) }\end{array}$ & $\begin{array}{l}\text { Embraces sensitivity, frequency of } \\
\text { occurrence and percentage anomalies. }\end{array}$ & When a river reach shows a one-class drop on the FAll rating scale. \\
\hline
\end{tabular}


Concerted macro-invertebrate-related monitoring along the five major rivers of the KNP commenced in 1996 with initiation of the RHP, using the South African Scoring System (SASS) methods. SASS is a standardised technique for monitoring macro-invertebrates, using a rapid bioassessment method where macro-invertebrates are sampled to family level from three biotopes (i.e. stones, vegetation and gravel/sand/mud) (Dickens \& Graham 2002; Gerber $\&$ Gabriel 2002). The ecological status at sites is determined by analysing SASS scores and the number of taxa found (Dickens \& Graham 2002).

During the KNPRRP, TPCs for macro-invertebrates were developed, based on the abundance of macro-invertebrate taxa and habitat condition, to be sampled within four biotopes (mud/gravel, stones-in-current, stones-out-ofcurrent, and marginal vegetation) (see Rogers \& Bestbier 1997). A bi-annual monitoring programme was envisaged (March and August) at five sites within the KNP's boundary, in each perennial river. The TPC would be exceeded when the number of macro-invertebrate taxa declined by more than $50 \%$ compared to previous records, indicating potential deterioration in conditions (Dickens \& Graham 2002; Gerber \& Gabriel 2002; Rogers \& Bestbier 1997). Another TPC was associated with habitat loss, to be audited using the SASS Associated Habitat Index sampling method (see Rogers \& Bestbier 1997). A loss of $20 \%$ or more would act as an early warning flag of detrimental physical and/or chemical impacts on macro-invertebrates.

\section{Application, refinements and assessment post-KNPRRP}

Although the five major rivers of the KNP have been monitored every 2 to 3 years under the RHP since 1996, feeding of this information through the macro-invertebrate TPC framework was not implemented until 2008. Perceptions about adequacy of sampling events achieved, and therefore ability to monitor trends, may have been responsible. Since the inception of the RHP, the Olifants River has been sampled four times (1998, 2002, 2008 and 2009), the Letaba, Luvuvhu and Crocodile Rivers twice (2007/2009, 2008/2009, 2005/2009 respectively) and the Sabie River once in 2009. However, in 2008, a decision was made to investigate application of available data. Data from Moore and Chutter (1988) were used as reference to compare data and assess the TPC for the Olifants River in July 2008. The TPC was exceeded (and tabled) because three of five sites had 50\% fewer taxa than in the mid-1980s (McLoughlin et al. 2009a). At the March 2009 KNP Conservation Management Committee meeting it was decided that a more intensive monitoring effort should be conducted, acting as an initial feedback loop. Results indicated that those sites that had exceeded the TPC in 2008 had recovered by June 2009. Higher river flows than those in 2008 may therefore have helped, and subsequently the TPC has been removed from the list of un-closed TPCs.

At present, there is a requirement to incorporate all SASSderived monitoring information into the Macro-invertebrate Response Assessment Index (MIRAI) model, developed for South African rivers (see Kleynhans et al. 2005). MIRAI was developed to determine the ecological category (class) of rivers, using macro-invertebrates as indicators of change in relevant environmental variables. MIRAI compares the present conditions of rivers (water flow/velocity, habitat, water quality) and macro-invertebrate presence (taxa diversity and abundance) to reference conditions (Kleynhans et al. 2005), aiming to identify causes (drivers) of change. For these reasons, new TPCs will be derived that are associated with macro-invertebrates and the MIRAI model. To date, there has been an inadequate capacity within the KNP to implement MIRAI modelling, and to derive relevant TPCs. This is, however, being addressed in 2010 via project collaboration with relevant macro-invertebrate specialists.

\section{Riparian TPCs}

\section{TPCs for sedimentation and habitat loss}

Rationale: Several of the larger rivers in the KNP are characterised by an unusual mix of both bedrock (underlying geological) and sandy sedimentary influence within the channel. The variable mix of sandy and underlying rocky areas creates a high degree of morphological ('habitat') complexity, ranging from slow-flowing, very sandy areas to very fast bedrock rapids, creating many niches for biota (Rountree, McLoughlin \& Deacon 2008). For example, the rivers of the KNP have the highest fish species diversities in South Africa; many species are critically dependent on the fast-flowing, well-oxygenated, in-stream bedrock habitats (Rountree, McLoughlin \& Deacon 2008).

Research has shown that the Crocodile, Sabie, Olifants and Letaba Rivers within the KNP fluctuate in space and time between various rocky and sandy conditions (Carter \& Rogers 1995; Rountree, Rogers \& Heritage 2000; Rountree \& Rogers 2004). There has, however, never been a time when there was no bedrock influence in these rivers. Under natural conditions, there is a tendency for some areas to become rockier whilst, simultaneously, other sections of the river become sandier (Rountree, McLoughlin \& Deacon 2008). Land-use changes within the upstream catchment (outside the KNP) have resulted in reduced flows, reduced floods and increased sediment inputs. These are thought to be causing a reduction in the availability of bedrock habitat because of the increased sediment storage. This results from increased sediment inputs and decreased sediment transport because of the reduced flows (Rountree, McLoughlin \& Deacon 2008). The original geomorphological indicators were generated along the Sabie River to measure and monitor the structural components of biodiversity (Rogers \& Bestbier 1997). Here, ecosystem response to changes in flow regime and increased sediment storage were defined according to five channel types (out of nine), characterised by bedrock influence and susceptibility to sedimentation (Table 5). It was envisaged that these channel types would be monitored by mapping changes observed on aerial photos, at various time intervals and after events such as droughts and floods of particular magnitudes (Rogers \& Biggs 1999; Rogers \& O’Keeffe 2003) (see Table 5). Changes in the channel characteristics that 
were used to set the lower limits of the geomorphology TPCs included (see Table 5), (1) directional loss in bedrock area at the whole river scale within the KNP and (2) the proportion of bedrock influenced geomorphic features at the finer geomorphic unit scale (Rogers \& Biggs 1999; Rogers and O'Keeffe 2003).

Application, refinements and assessment post-KNPRRP: The geomorphology monitoring (described above) was tested within the KNP SAM system during 2007. Although based on extensive research, the subjectivity of measuring various geomorphic units along representative reaches, and expert input required, was a major problem and hence was unsustainable (McLoughlin et al. 2009b). An early feedback loop within a SAM system should ask the question whether the monitoring programme is feasible. If not, this must be reviewed and changed where appropriate. In addition, new thinking suggested that the geomorphology TPC was inadequate because it assumed very gradual, incremental change in the morphology of the river channel over time, which was not suitable for flagging problems before sedimentation problems arose (Rountree et al. 2008).

Hence, using the best available knowledge, a new approach was initiated in 2008 for 'red-flagging' potential sedimentation problems, or for providing the relevant ecosystem information if rehabilitation is required. This was based on analysis using historical aerial photographs, involving a count of all rapid sections along the length of a bedrockinfluenced river. Trends would be established relative to the 1940s where conditions were assumed more pristine, and a TPC determined, based on the rate of rapid section (critical habitat) loss over time (Rountree, McLoughlin \& Deacon 2008). It was soon realised, however, that a simple count of rapids was inadequate; more information was required to assess the condition of the channel in terms of degradation by sedimentation. Thus, the geomorphic TPC was revised to monitor only in the most sensitive sites along the river where increases in sedimentation could be flagged the fastest (Rountree, McLoughlin \& Deacon 2008). The process now includes (1) assessing change in the size (width) of the active channel (in-stream habitat availability) and (2) functioning of exposed bedrock habitats important for biota.

In 2008, the TPC was tested successfully along the Olifants River. Pertinent sediment-sensitive sites were demarcated and geo-referenced using a Geographic Information System (example Figure 3 [a]). Mean width of the active channel is measured using pre-selected transects across the mapped active channels (Figure 3 [a]). A geomorphic scoring system (developed using expert knowledge) (see Figure 3 [b]) is used to calculate a Rocky Habitat Index (RHI) in selected areas of the river (polygons, Figure 3 [a]). A once-off historical analysis of trends is carried out to set first estimates for TPCs associated with active channel width (see Figure 4 [a]) and the RHI (linked to an ecological category) (Figure 4 [b]) that can then be monitored against, in future, to audit the TPCs (Rountree, McLoughlin \& Deacon 2008). Trends emanating from the interpretation of this monitoring will provide the broader-scale context involving geomorphic changes occurring within the rivers. Additionally, pertinent decision support protocols, linked to this TPC system, are under development.

\section{TPCs for biotic response to sedimentation and habitat loss \\ Rationale}

The riparian tree species Breonadia salicina was recognised as a good indictor of bedrock influence because it grows in close proximity to the active channel and in close association with bedrock-related habitats (Van Coller 1993). Additionally, B. salicina germinates abundantly on any substrate type, however, it only establishes on exposed bedrock because this substrate allows for sufficient anchorage during flooding events, which is important for individual persistence. Hence, the population structure exhibited by B. salicina will be affected detrimentally by the smothering of bedrock via increased sedimentation during the establishment phase of its life cycle, with adult populations progressively declining in abundance (Mackenzie, Van Coller \& Rogers 1999). Importantly, current knowledge suggests that for healthy B. salicina populations, the size-structure should display a negative J-shaped curve on bedrock-influenced, geomorphic habitats (Figure 5). Three parameters that denote characteristics of population structure are being used to assess the Breonadia TPC (Mackenzie, Van Coller \& Rogers 1999), (1) the goodness of fit $\left(\mathrm{r}^{2}\right)$ of a linear regression of population structure, (2) the slope of the linear regression (x-coefficient) and (3) the y-intercept (constant) of the linear

TABLE 5: The original geomorphology thresholds of potential concern proposed for the Sabie River, Kruger National Park, monitoring for the structural biodiversity components.

\begin{tabular}{|c|c|c|c|}
\hline Measurement criteria & Measurement units & Measurement scale & Thresholds of potential concern \\
\hline $\begin{array}{l}\text { Selected channel types ( } 5 \text { of } 9 \text { ) in } \\
\text { designated representative reaches: }\end{array}$ & $\begin{array}{l}\text { Area of selected geomorphic units } \\
\text { ( } 4 \text { of 14) on aerial photos: }\end{array}$ & $\begin{array}{l}\text { Temporal: Every } 5 \text { years and events } \\
\text { (floods, droughts) greater than } \\
\text { 1:25 year return interval }\end{array}$ & $\begin{array}{l}\text { Directional loss of bedrock influence and } \\
\text { winter flow ( } 20 \text {-year prediction) }\end{array}$ \\
\hline - Alluvial anastomosing & - Anastomosing bar & - $10^{2}-10^{3} \mathrm{~m}$ per representative reach & - Bedrock core bars $50 \%$ cover or more \\
\hline - Mixed anastomosing & - Bedrock pavement & - $20 \times 20$ m grid square & $\begin{array}{l}\text { - Three units must be } 2 \%-10 \% \text { of total } \\
\text { area }\end{array}$ \\
\hline \multirow[t]{2}{*}{ - Mixed pool-rapid } & & & Pool-rapid channel types: \\
\hline & & & $\begin{array}{l}\text { - Lateral and point bars, } 20 \% \text {, and pools, } \\
15 \% \text { of total area }\end{array}$ \\
\hline
\end{tabular}


regression. Mackenzie, Van Coller \& Rogers (1999) explain the biological interpretations for the initial parameter values set, and provide details of a population model (for predictive purposes) and monitoring requirements linked to this TPC.

\section{Application, refinements and assessment post-KNPRRP}

The first non-research-related monitoring effort associated with the Breonadia TPC was completed only in August 2008.

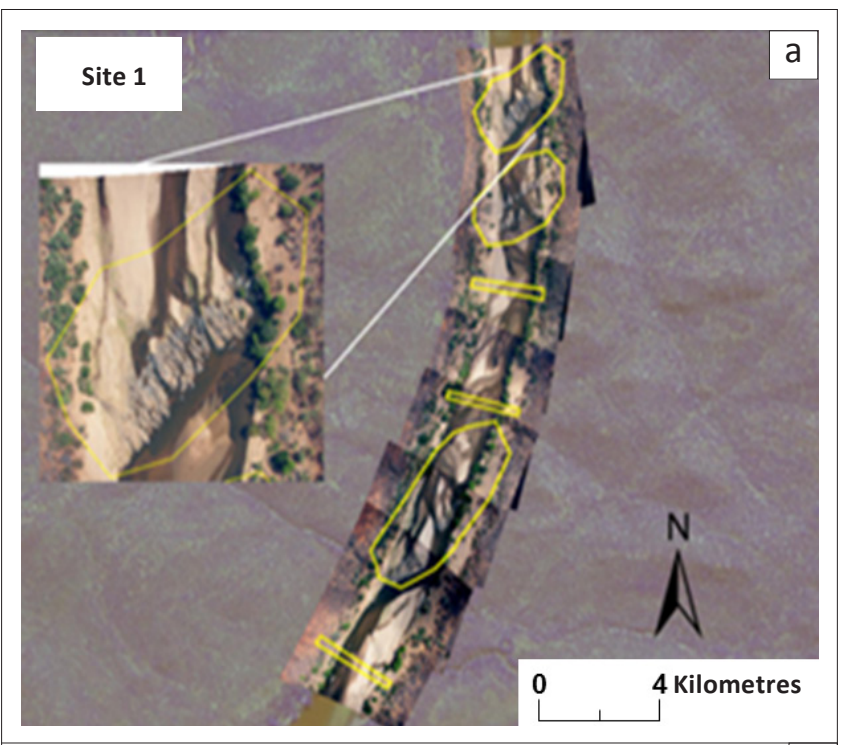

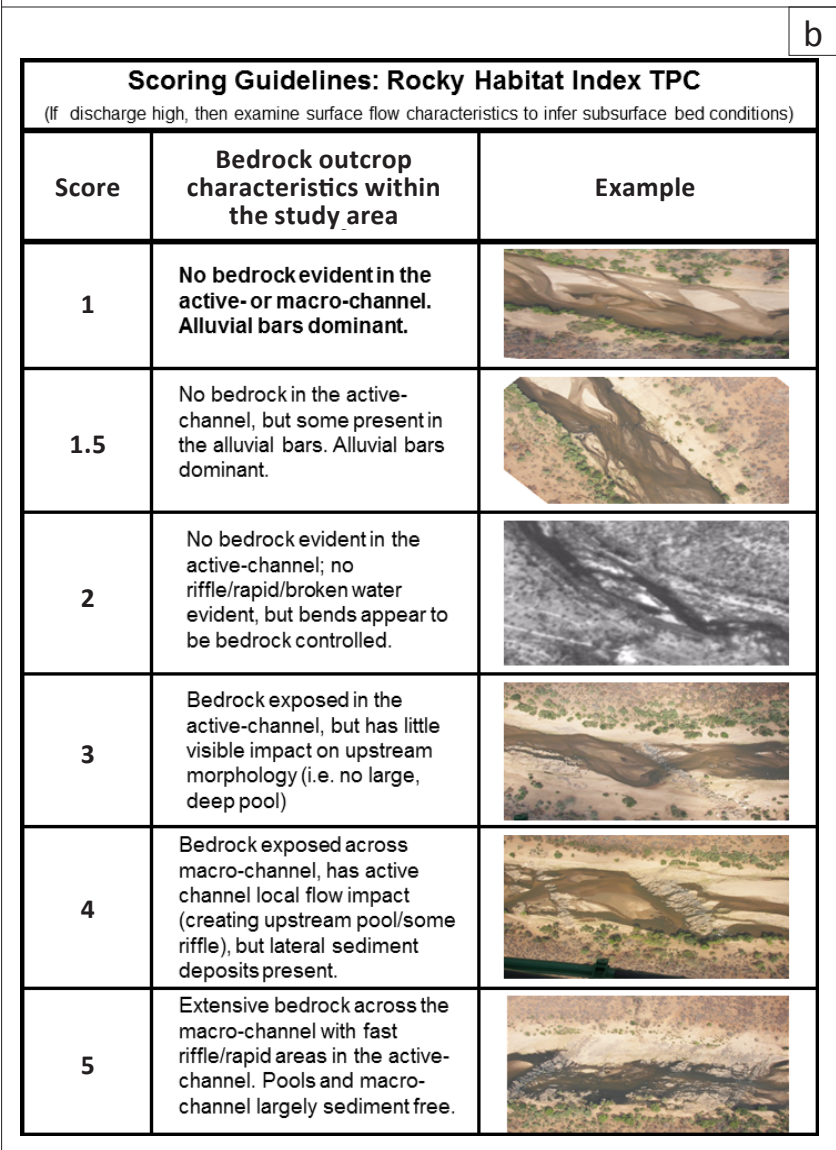

Source: Rountree, M., McLoughlin, C.A., Mackenzie, J., Deacon, A. \& Sithole, H., 2008, 'Kruger National Park TPC data collection, testing and implementation', unpublished Water Research Commission report.

FIGURE 3: Methodology for the new geomorphology thresholds of potential concern concept. (a) Example of a site selection and demarcation, (b) Rocky Habitat Index scoring system, as tested on the Olifants River.
Therefore, since the TPCs' inception, major assessment opportunities have been lost. There was, however, a large, infrequent flood disturbance in the Sabie River during February 2000, impacting the B. salicina populations. This resulted in further interest for post-graduate work. Dowson (2009) refuted assumptions by Mackenzie, Van Coller \& Rogers (1999) that the B. salicina populations would recover within 4 years after such a large flood event. This provided important information for further use of this tree as an indictor of bedrock influence, linked to biodiversity goals. Pertinent refinements to the Breonadia TPC were made, including an 8-year predicted population recovery period after a large flood event.

In addition, although the Pool-rapid channel type is most sensitive to increasing sedimentation, and was targeted for monitoring B. salicina (Mackenzie, Van Coller \& Rogers 1999), new knowledge suggested a need to move the monitoring sites to the Mixed Anastomosing (see Van Niekerk et al. 1995) channel type. Reasons included (1) there is a naturally occurring low abundance of B. salicina in the Pool-rapid channel type and (2) the Pool-rapid channel type undergoes more frequent state change (natural) between the sedimentdominated (Braided) and bedrock-dominated (Pool-rapid) states (Rountree pers. com.). It is, therefore, difficult to tease out natural from unnatural sediment-related dynamics.

The first TPC audit associated with the B. salicina indicator was completed in 2008 after the monitoring effort in August of that year, resulting in the TPC being tabled at the KNP Conservation Management Committee meeting of May 2009 (see Appendix 1 for structure and content of the feedback report). The response was to resample the $B$. salicina populations in 2009 , to further investigate population recovery after the 2000 flood (initial feedback loop). Although the TPCs were still exceeded, there was evidence to suggest population recovery, that is, recruitment and seedling establishment (absent during 2008). It is important to note that there is a requirement, currently, to reassess the TPC parameters, because initial values were estimates based on available knowledge (Mackenzie, Van Coller \& Rogers 1999) and monitoring sites were changed to the Mixed Anastomosing channel type. The re-assessment of threshold parameters are being tested under a current Water Research Commission project titled 'Application and Testing of a Strategic Adaptive Management System for Freshwater Protection' (WRC project number K5/1797), using all monitoring data collected to date. Learning associated with the Breonadia TPC has been largely biophysical in nature. For example, B. salicina populations require more than 10 years for recovery after a large flood disturbance (McLoughlin et al. 2009b). This refutes the 8-year prediction made (Dowson 2009) subsequent to the initial estimate of 4 years by Mackenzie, Van Coller \& Rogers (1999). Furthermore, the Breonadia TPC example highlights the need to select the most appropriate sites for monitoring the TPC indicators (McLoughlin et al. 2009b).

\section{TPCs for biotic response to changes in flooding regime}




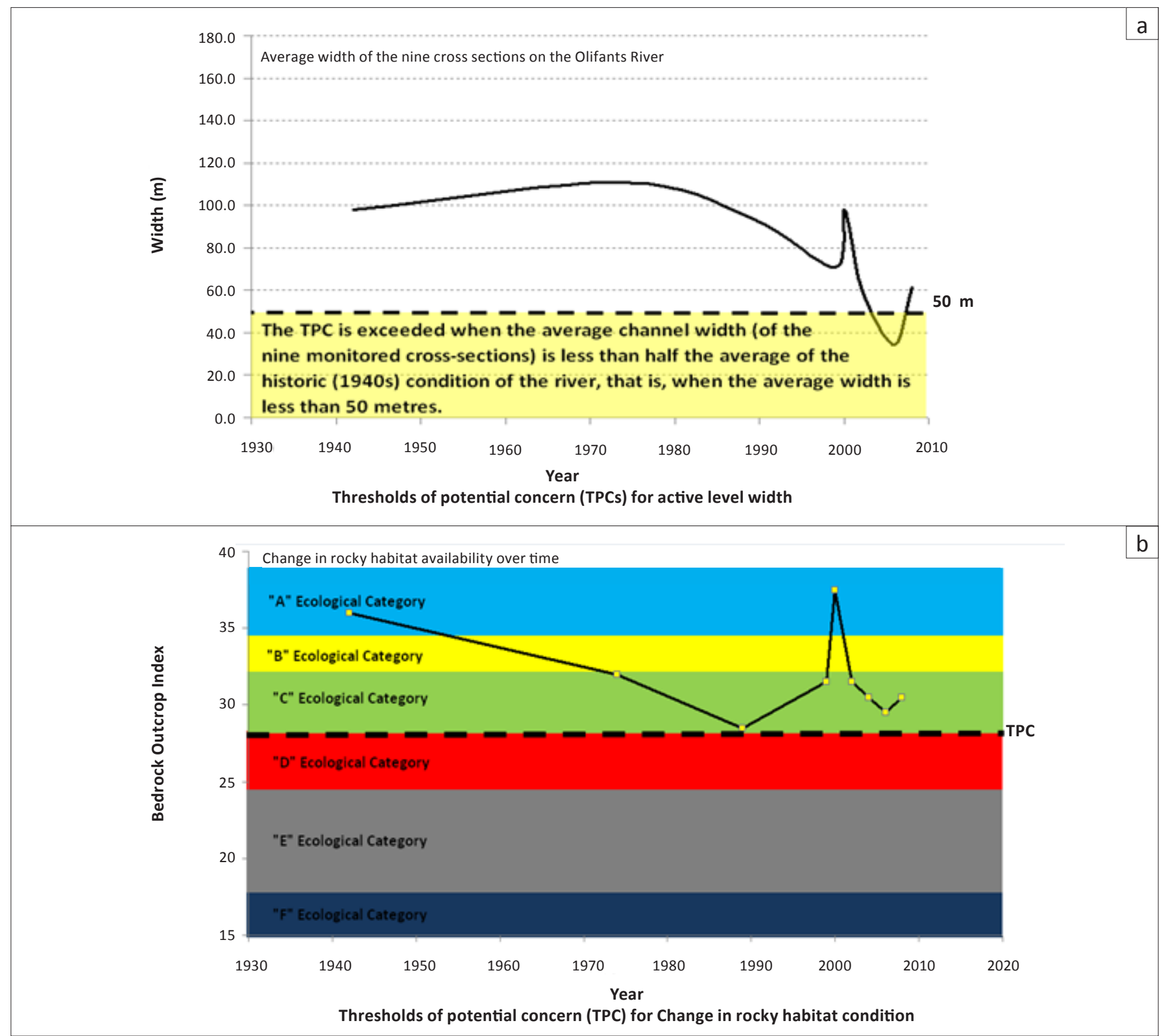

Source: Rountree, M., McLoughlin, C.A., Mackenzie, J., Deacon, A. \& Sithole, H., 2008, 'Kruger National Park TPC data collection, testing and implementation', unpublished Water Research Commission report.

Broken black line, threshold level associated with river habitat condition.

Exapmle taken from Olifants River.

FIGURE 4: Development of the new geomorphology thresholds of potential concern.

\section{Rationale}

Although terrestrial woody species do occur within the riparian zone, under natural conditions, there is a decreasing abundance closer to the active channel. An increasing terrestrial species abundance in riparian zones threatens biodiversity (Mackenzie, Jacoby \& Rogers 2003). The reasons for this increase include (Mackenzie et al. 2003) (1) the loss of riparian species while terrestrial species abundance remains unaltered, because of a reduced recruitment of riparian individuals with less flooding, or loss of established riparian plants from drought, (2) an increase in terrestrial species while the riparian species abundance stays the same, because of reduced flooding frequency - terrestrial species usually not tolerant of flooding conditions may now establish closer to the active channel and (3) a decrease in riparian species abundance while terrestrial species numbers increase, because of severe reductions in flow over time, resulting from upstream abstractions and barriers to flow.

The current TPC for terrestrialisation is framed as the ratio of the abundance of key terrestrial woody species, to the abundance of an equal number of key riparian species, along an index of flow frequency and availability of water from the water table (see Mackenzie et al. 2003). Four woody species used to assess the Terrestrialisation TPC are Combretum erythrophyllum and Syzygium guineense (riparian); Dichrostachys cinerea and Acacia nigrescens (terrestrial).

\section{Application, refinements and assessment post-KNPRRP}

The first non-research-related monitoring effort for the Terrestrialisation TPC was completed in 2008, within four sites along the Sabie River and follow-up monitoring took 


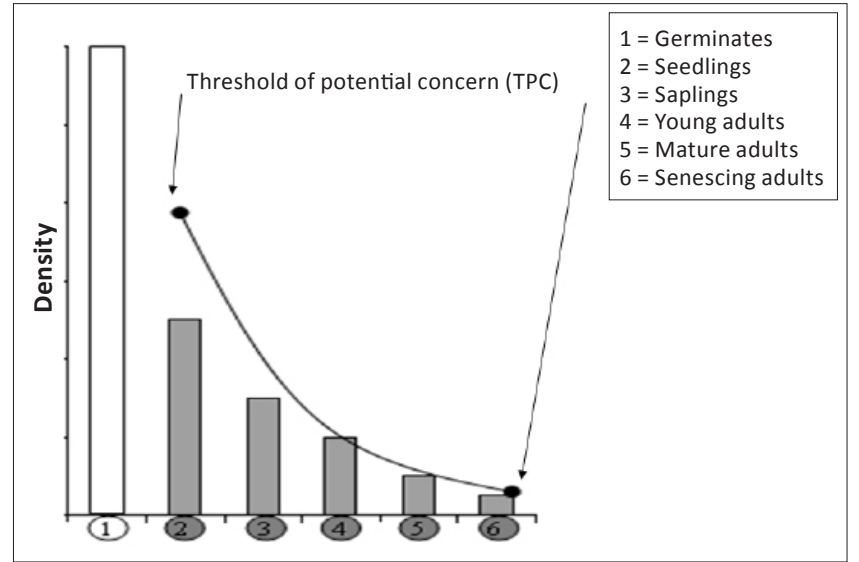

Source: Mackenzie, J.A., Van Coller, A.L. \& Rogers, K.H., 1999, Rule Based Modelling for Management of Riparian Systems, Water Research Commission Report No. 813/1/99, WRC, Pretoria.

Breonadia salicina population size class 1 (Germinates) is not utilised in TPC auditing.

FIGURE 5: The negative J-shaped population structure for all non-germinant, established individuals of Breonadia salicina, used for auditing of thresholds of potential concern.

place in August 2009 (McLoughlin et al. 2009b). Sites from KNPRRP (see Mackenzie et al. 2003) were extended to $100 \mathrm{~m}$ (from $20 \mathrm{~m}$ )-wide belt transects to sample the relevant woody species adequately. The first TPC audit associated with the Terrestrialisation TPC was achieved in 2008 and later in 2009, with no TPC exceedances being recorded. One site was, however, considered inadequate for monitoring and required replacing. An assessment about the future use of the Terrestrialisation TPC in its present form is currently being carried out. Newer techniques associated with riparian vegetation condition have been developed by specialists working for the DWA and can potentially be used (McLoughlin \& Mackenzie 2009). Ultimately, it is envisaged that these methods will be simpler to implement, but will still provide necessary information within the TPC framework.

\section{Lessons learned}

The implementation of river TPCs within the KNP SAM system since the KNPRRP, and changes instigated to date, provide key lessons about the practical application of TPCs within SAM, including the use of adaptive feedbacks loops that are important for evaluation and learning. It is envisaged that these 'lessons learned' may be beneficial to other organisations that seek to adopt SAM. One example within the South African context is the Catchment Management Agency. These institutions are required, under the National Water Act (36 of 1998), to practise de-centralised, stakeholderengaged, adaptive water resource management to meet sustainability, equity and efficiency objectives. Some of the $\mathrm{KNP}$ river lessons include the following:

\section{People: Motivated, dedicated and adaptable}

The success of the newly implemented 'Rapid Response System' within the KNP (with integration into the broader catchment situations) is attributed to the dedication of the KNP river technician. This person is essential as a catalyst for various feedbacks associated with the different 'worry levels' mentioned above. In addition, this person is critical in collecting, collating and distributing the information each month, so that relevant people can make use of it in decision making. The 'management $\log ^{\prime}$ is also updated monthly by this person; this provides critical information for evaluating effectiveness of the system. Without such a person, it is doubtful whether this information would be made available on an ongoing basis, at the correct times and to the right people (without the luxury of an expensive, automated data system). The SAM TPC system is highly dependent on generation of suitable data and information that is disseminated and actually used. Therefore, employing motivated and dedicated people of this type is an important enabling factor, critical at the monitoring, information generation and dissemination stages of SAM, for later evaluation and reflection processes. At the reflection and decision-making stages, motivated and 'adaptive thinking' individuals are also required to disseminate information in appropriate ways, so that suitable discussion on issues arising from this information is facilitated.

\section{Suitable benchmarks against which to measure indicators}

The importance of a benchmark against which to monitor river flows is a critical enabling factor for adaptive feedback processes, as applied to river flow management (Pollard \& Du Toit 2009). With the implementation of a 'Rapid Response System' within the KNP, defining which benchmarks to use that are suitable must also be emphasised. The Crocodile River provides a good example, as the appropriateness of the IFRs for the river that were developed over 10 years ago is proving to be a major stumbling block. This is further exacerbated by the deteriorating river flows in the Crocodile River. Broader recognition of these IFRs as being outdated, exacerbated by lags in implementation of the newer, improved Ecological Reserve determination methods, has caused some confusion about further implementation of the KNP 'Rapid Response System' system for this river - for example, when to initiate various responses from the KNP to outside water resource managers and knowing when to make legitimate calls for improvements in river flow, rather than merely antagonising other stakeholders. This situation leads potentially to a loss of cooperative behaviour and trust between stakeholders (e.g. KNP to catchment managers and other water users) and is exacerbated when there is disagreement between stakeholders on the merits of an existing benchmark, leading to frustrations about when actions must occur. A major risk is loss of motivation by key people (as described above), and a subsequent loss in momentum of the adaptive feedback processes. Therefore, determining suitable and acceptable benchmarks against which to monitor system change, and acting at the appropriate times relative to these, must be encouraged and actively sought after. In addition, the acceptance and buy-in from all key stakeholders is important.

\section{Information: Generation and use}

Adaptive management implies the production of knowledge through policy and management actions, and that this knowledge is disseminated among all interested groups, 
and is actually used (Stankey, Clark \& Bormann 2005). In this context, knowledge is continually being constructed and reconstructed as various people interact with each other and as new information becomes available. Learning from the generation of new knowledge is, however, a complex process, and learning can be derived from both technical and social processes (Stankey et al. 2005). On one hand, an increased understanding about systems, such as the socioecological and socio-economic systems and their interactions, is a form of technical knowledge. However, enhancing the social processes associated with how this new understanding may be better formulated, communicated and incorporated into organisational policies and management, is critical. Although deficient learning can result from a lack of data and resultant information, in other instances the information is available, but not made accessible, or is presented in a manner not conducive to learning. It is important to note that the social processes needed to facilitate communication and debate among an organisation's members may be lacking. Here, feedback of information is essential for enhancing information flow within an adaptive management context (Stankey et al. 2005).

The issues highlighted by Stankey, Clark \& Bormann (2005) are also applicable to the implementation of the KNP river SAM system over the last decade. Firstly, within SAM, monitoring programmes where information is derived must be developed and prioritised according to the Objectives Hierarchy. This allows for explicit linkages between the higher-level, value-laden objectives and those on the ground, that is, the TPCs (see section on 'KNP river TPCs - future directions', refinements to the river Objectives Hierarchy). Generation of information, via implementation of these strategic monitoring programmes, then plays a critical role for effective evaluation and reflection. A lack of monitoring (prior to 2008) associated with the Geomorphology, Breonadia and Terrestrialisation TPCs within the KNP SAM system resulted in no information having been derived to make assessments, thus opportunities for evaluation and reflection were lost. Learning only occurred after 2008 once the first monitoring and information feedbacks were instigated, as discussed in this paper.

Secondly, once derived, information must then be made available to all pertinent people within an organisation, otherwise scarce resources spent on information collection are wasted. Although monitoring associated with the instream TPCs (fish and macro-invertebrates) within the KNP was carried out over the past decade, this information was not made available in an adequate form to decision makers. Thus, managers had very little idea about the condition of the river ecosystems in terms of these indicators, limiting the urgency of responses that were made. In 2008, reporting and tabling of the fish and macro-invertebrate TPCs for the Olifants River, using available historical information generated via monitoring, did increase awareness about the extent of deterioration of the Olifants River over time. This set in motion the initial adaptive loops, that is, the instigation of more detailed monitoring to further investigate conditions within the river, for subsequent action. It is important to note that, because this information was not made wholly available in the past, earlier management opportunities resulting from this information were potentially lost. Although stoppages in river flow occurred in 2005, it is notable that more concerted action commenced in 2008 with the onset of a crisis: the Nile crocodile deaths in the Olifants River Gorge (McLoughlin, Deacon \& Sithole 2009a).

Thirdly, within SAM, pertinent information must actually be used within the decision-making process, relative to management objectives, so that adaptation of actions can be made where appropriate. Importantly, the amount, detail and format of the information must be applicable at different organisational levels. For example, scientists within the KNP may deal with the detailed data and information associated with biophysical conditions in the river (e.g. for the Breonadia TPC), managers may require only broader information on this, but a clear indication of trends related to drivers, like river flows where management action can be applied. Allowing for better visualisation of information, as occurs for the river flow data within the KNP 'Rapid Response System', facilitates information transfer and enhances the assessment and evaluation environment for decision making. However, improving this feedback system is an ongoing process as further learning occurs.

\section{Implementation lags: Key processes}

Within the SAM TPC system, lags in implementation of various components (e.g. monitoring) should be expected. The key issue, then, is how to define and deal with these. Important questions asked concerning the deteriorating KNP river flow situation are: which lags are acceptable and which are not? Importantly, contingency plans should be put in place to deal with unacceptable lags. The Crocodile River situation, with lags in development of methods to calculate the new Ecological Reserve benchmarks provides a good example of this. The contingency in this case was implementation of the three-tiered management response system for the Crocodile River (see Figure 2), in relation to the older IFR benchmark levels, until availability of the newer Ecological Reserve benchmarks (see section on 'KNP river TPCs - future directions').

Another example of a lag within the KNP SAM system is a delay in the implementation of the intended evaluation processes associated with the 'Rapid Response System'. Specifically, there should be discussion within the KNP Conservation Management Committee on how the 'Rapid Response System' has worked over the previous period, that is, what the associated river flow outcomes were, which actions worked or did not work, and how to adapt and improve the system for future application, to improve river flow conditions ultimately. An important lesson is to follow through on plans; although there may be general agreement on particular systems, this does not automatically translate into implementation of adaptive processes. Implementation 
requires dedicated, motivated and adaptive people (champions), to move the processes forward. Without such people, the adaptive feedback process is likely to stagnate, and future management adaptation, using past actions to learn from, will not be forthcoming.

\section{Timing: Between monitoring and management action}

The timing of feedback processes within an organisation, that is, from data and information collection to decisions made using this information, must be considered when implementing TPCs within SAM, to increase strategic use of information. The 'Rapid Response System' within the KNP was developed to deal with quick management responses that were required, associated with an indicator (in this case river flow that can change within short time periods). Within the $\mathrm{KNP}$, the assessment and reflection opportunity once every two months, using the TPC tabling system, was not appropriate for this indicator. Adapting past management responses, from within the KNP to achieve the desired state, that is, compliance with IFRs, was therefore difficult. This situation generated frustration within the KNP SAM system, while ongoing deterioration of river flow conditions occurred within rivers, because actions could not be adequately assessed and adapted to improve future implementation of the 'Rapid Response System'. Essentially in practice, feedbacks within SAM require different time frames, dependent on the type of drivers, and indicators used within the TPC framework, these issues must be considered.

\section{Feasibility: Monitoring programmes}

Ongoing assessment about the adequacy of monitoring programmes, as used within the SAM TPC framework, is important. Feasibility of monitoring methods to assess TPCs, in terms of cost or expertise required for example, should be considered in detail before this is included within an organisation's management plans. Unfeasible monitoring programmes can lead to lags in implementation of the monitoring required to assess components of a TPC system. The result is a lack of information that should have been made available for decision making, to reflect on the effectiveness of the selected and implemented management actions. Adaptation of future management actions, based on information about past management actions is then hampered. A good example is the Geomorphology TPCs that were originally developed during the KNPRRP of the 1990s. Although based on sound research and principles, the expertise required to implement these TPCs over the longer term may have resulted in no monitoring taking place over a decade since the TPCs' inception. A simpler system was necessitated, with less expert input required, but that could still provide relevant information about the geomorphic state of the rivers. This has been achieved with the new Geomorphology TPCs that have been developed recently for the KNP rivers.

\section{Refinements: Ongoing TPC requirement}

TPC development within SAM is not a once-off process, but rather, ongoing assessment and refinement over time is needed. Because of the large amounts of uncertainty and lack of complete knowledge about systems, the development of TPCs often commences with basic first estimates involving the relevant indicators of change. As new information is generated, via monitoring efforts or further research, feedbacks must then focus on evaluating the appropriateness of the TPCs. Using current knowledge, thresholds must then be refined to improve the TPC over time. Ideally, ongoing learning about the system under consideration will then also occur. The Breonadia TPC development and refinement process within the KNP demonstrates this point well. A lesson is that changing management actions, as a consequence of new information generated via monitoring efforts, is not always an outcome in SAM. Rather, learning processes occur within the TPC process itself, that is, increased understanding about drivers of change, indictors of these drivers, and pertinent threshold parameters to set and apply within the TPC framework.

\section{Adaptive feedback loops: Identification and closing}

Over more than a decade, one major focus of the KNP SAM system associated with river management has been on implementation of the 'operational' components, which are the monitoring and reporting related to river flows (IFRs) and water quality. Although very important, under this situation there has been some loss of recognition for why these operational components were originally conceptualised under the National Water Act (related to water resource sustainability and the delivery of ecosystem goods and services, for human benefit). In the KNP context, these benefits are associated with SANParks' mandate to maintain biodiversity, with links to eco-tourism outcomes, among others. This provides an important adaptive management lesson, in the South African context, particularly for catchment management agencies that are tasked with giving effect to the National Water Act, and in this case particularly freshwater protection. Implementing the Ecological Reserve in an adaptive manner requires furthering understanding about the effects of the Ecological Reserve on the biophysical components of the system, ultimately linked to maintaining the delivery of ecosystem goods and services, for human benefit. Associated information must be fed back richly into learning, ultimately, to improve water resource management over the longer term. In essence, achieving agreed upon sustainability goals, over and above other (e.g. social and economic) objectives.

The main lesson here is identifying and then actively attempting to close adaptive cycles within the SAM framework, along with explicit learning. Notably, various stakeholder sectors within any catchment context will have various priorities and perceptions associated with where 'closing of the adaptive cycle' occurs. There are potentially many nested adaptive cycles occurring simultaneously 
within a broader SAM system. For instance, there has been a major focus at the catchment scale within South Africa on the implementation of various strategies to allocate water adequately to different water use sectors, while meeting Ecological Reserve targets at strategic points along the river. Refining and improving practices to achieve this is a key factor, involving learning about how to adapt (e.g. dam operating rules, validating water use and re-licensing, regulating use via water restrictions and so on) along the way to achieve this desirable outcome. However, in order to meet the requirements of the National Water Act, there is an obligation over longer time scales for directed learning within SAM, that is, about how implementation of the recommended flow regimes (and water quality) generates the desired state (vision) of the resource under management. For example, achieving or maintaining the recommended management class for sustainability, or the equity/economicrelated targets. It is this process of learning and subsequent adapting to meet these types of high-level objectives that will result in a more active application of SAM, as applied within the context of the South African National Water Act.

\section{Kruger National Park river TPCs - future directions}

The river TPCs and associated monitoring plans have the longest history within the KNP, since the inception of SAM within the KNP during the KNPRRP of the 1990s (see Rogers \& Bestbier 1997). However, a lack of full implementation after a decade has now necessitated a broader re-evaluation. Revision of rationale and a reflection on objectives and best available indicators and monitoring methods, in line with management goals, is currently underway. This reflection process is not within the scope of this paper; however, an overview of pertinent initiatives currently taking place is provided below.

Firstly, an assessment of the KNP Objectives Hierarchy has identified the following potential problem areas related to the strategic objectives for river management, (1) too many levels associated with the hierarchy of objectives, generating undue complexity, (2) the proportion of value-laden and research objectives is too high, compared to the finer level of detail where 'doing something' is required, (3) a need to link the higher level, value-laden objectives higher up with more rigorous and explicit end-points (TPCs), thus to prioritise monitoring activities to guide management in the achievement of goals, this being a key component of SAM and (4) no link to socio-ecological processes and understanding required, this now being an important focus for integrated catchment management and adoption of SAM wider in the catchments.

Hence, a modified Objectives Hierarchy for river management has been recommended, (see Figure 6), but still requires further reflection during the KNP SAM revision process. These changes include the following, (1) the functional processes and composition/structure and pattern objectives are not explicitly stated as before, but integrated within the biodiversity-related objectives, for clearer interpretation, (2) the research objectives have been grouped separately, and broken down into relevant sub-objectives related to both biophysical and governance (social) aspects for more clarity on research needs (with necessary linkages), (3) research objectives, related to generating further understanding and maintenance of TPCs has been made more explicit, (4) there are more explicit links between higher level aquatic biodiversity objectives and the more detailed end-points (TPCs) to guide relevant monitoring in relation to goals, (5) TPCs are now explicitly determined per river, an important aspect because of differences between river characteristics and given knowledge per river system and (6) the 'social understanding objective' has been incorporated, requiring linkages with the KNP Social Science Objectives Hierarchy where appropriate (for further development).

Secondly, important to consolidation of the KNP river TPC system is the recognition of and integration with relevant national processes associated with fostering sustainable water resources. Specifically, the Ecological Reserve process, including implementation of environmental flows and monitoring initiatives where pertinent.

\section{The Ecological Reserve}

The current Ecological Reserve determination processes provide a more realistic estimate of environmental flow requirements compared to the IFR-based system, and these requirements are legally justifiable under the National Water Act (once signed off by the Minister of Water Affairs). The Ecological Reserve (incorporating water quality also, but only referring to river flows in this instance) has been determined for the Crocodile, Sabie, Olifants and Letaba Rivers, albeit at varying levels of detail and confidence. Further studies are in progress (or are planned) to update older versions (see Table 6). To date, effective implementation of this Ecological Reserve has, however, not taken place, a consequence of various catchment wide lags in implementing the National Water Act. A key factor is that most catchments associated with the KNP are highly water-stressed (the Sabie River is an exception) (see DWAF 2004a; DWAF 2004b; DWAF 2004c). It is believed that rapid implementation of the Ecological Reserve is dependent on significantly increased water restrictions on users, resulting in large economic impacts in the surrounding catchments, for example, on irrigation farming in the Crocodile River Catchment (Jackson, pers. com.).

Hence, a longer-term, progressive realisation of Ecological Reserve implementation is envisaged for most major rivers of the KNP, but implementing strategies to achieve this is now critical. The KNP is playing an increasingly active role, for example, in the development of the Inkomati Catchment Management Strategy during March 2010 (as required by the Water Affairs Ministry), after a series of public participation workshops run by the Inkomati Catchment Management Agency. Although not discussed further in this paper, the 
authors acknowledge that water quality monitoring and management does require further improvement.

The practicality of water resource managers delivering the Ecological Reserve has, however, also contributed to lags in implementation. It is encouraging that, to date, improved hydrological models and methodologies to implement the Ecological Reserve have been developed and tested, such as the Spatial and Time Series Information Modelling (SPATSIM) software (see Hughes, Mallory \& Louw 2008) for the Groot Letaba River system and the Mike FLOOD WATCH and Water Resource Modelling Platform (WReMP) (see DWAF, 2008b) for the Crocodile East River system. The idea is to mimic natural flow variability as much as possible. Dam releases and/or water restrictions will ideally be calculated and applied to meet both the Ecological Reserve requirements (progressively realised over time where pertinent) with adequate water supply to the various water user sectors. A requirement will be that these sectors need to become more efficient in their water use. The KNP is collaborating with catchment management agencies on various implementation strategies associated with these developments. Monitoring river flows associated with an adaptive feedback system is one important initiative being implemented, involving the integration of KNP river SAM processes wider into the catchment areas.

\section{Aquatic and riparian ecosystem monitoring}

The KNP is consolidating existing knowledge, using updated understanding about the physical drivers (water quality, flow and sediment load) from the upstream catchments that influence the biophysical conditions (at different temporal and spatial scales) of the rivers flowing through the KNP (see Rountree et al. 2008; McLoughlin et al. 2009b for details). In addition, integration of the KNP's TPC monitoring programmes with Ecological Reserve monitoring processes is being sought where appropriate. For example, Kleynhans et al. (2009) propose integration of Ecological Reserve monitoring with that of the River Health Programme, forming the basis of an integrated Ecological Water Resource Monitoring system. It is envisaged that this should be undertaken within a structured decision-making framework, following the principles of SAM (DWA 2009) (see Figure 7). The main purpose is to provide a decision framework within which monitoring results can be interpreted in terms of the attainment of specified objectives, that is, Ecological Specifications (EcoSpecs) and TPCs linked to an ecological category. The ecological category is associated with river health conditions linked to a vision set for a particular river.

The Ecological Water Resource Monitoring system uses the newly developed and available monitoring techniques called Rapid Habitat Assessment Methods (see DWA 2009). Rapid Habitat Assessment Methods were developed because capacity within South Africa is a major stumbling block to longer-term implementation of the Ecological Reserve process. Essentially, before biotic indicators are monitored (using River Health Programme tools: the FRAI, the MIRAI), data are collected using the more feasible Rapid Habitat Assessment Methods, and then analysed. The premise is that suitable habitat conditions will indicate the likely presence, abundance and frequency of occurrence of particular biota. The associated TPC system will act as a 'red flag' prior to (potential) requirements of the more resource-intensive biotic methods (see Figure 7). Although originated as a tool for in-stream conditions, application of Rapid Habitat Assessment Methods to riparian vegetation has also been developed (Mackenzie, pers. com.) and will be used to make assessments associated with the KNP Terrestrialisation TPC and others. The KNP is spearheading initiatives to implement this new monitoring and decision support system (Figure 7). Within the KNP SAM system (and wider), this will provide further learning opportunities associated with information generation and storage, interpretation, dissemination and use.

\section{Acknowledgements}

We thank Llewellyn Foxcroft for his critical inputs to this manuscript, and for useful suggestions. Funding from the Water Research Commission allowed further investigation into testing and refining the KNP river TPCs and associated processes, with the many outcomes incorporated in this paper. We are also grateful for the enthusiastic inputs associated with ongoing KNP TPC developments, provided by James Mackenzie, Mark Rountree and Jacques Venter. In addition, the broader support given by Rina Grant, Stefanie Freitag-Ronaldson, Harry Biggs, Kevin Rogers and Freek Venter has made this work possible.

\section{References}

Biggs, H. \& Rogers, K.H., 2003, 'An adaptive system to link science, monitoring and management in practice', in J.T. du Toit, K.H. Rogers \& H.C. Biggs (eds.), The Kruger Experience: Ecology and Management of Savanna Heterogeneity, pp. 59-80, Island Press, Washington.

Breen, C.M., Dent, M.C., Jaganyi, J., Madikizela, B., Maganbeharie, J., Ndlovu, A., et al., 2000, 'The Kruger National Park Rivers Research Programme', Water Research Commission report TT 130/00, WRC, Pretoria.

Carter, A.J. \& Rogers, K.H., 1995, 'A Markovian approach to investigating landscape change in the KNP rivers', Report no. 2/95, CWE, University of the Witwatersrand, Johannesburg.

Council for Scientific and Industrial Research, 2002, Ecological Reserve Determination for the Crocodile River Catchment, Incomati System, Mpumalanga, Report no. ENV-P-C 2002 009, CSIR, Pretoria.

Department of Water Affairs and Forestry, South Africa, 1991, Proceedings of a workshop on the Flow Requirements of Kruger National Park Rivers, Report TR 149, Department of Water Affairs and Forestry, Pretoria.

Department of Water Affairs and Forestry, South Africa, 1996, South African Water Quality Guidelines: Aquatic Ecosystems, vol. 7, 1st edn., The Government Printer, Pretoria.

Department of Water Affairs and Forestry, 1998, River Health Programme, Internal Report, viewed n.d., from http://www.dwaf.gov.za/iwqs/rhp/state_of_rivers.html

Department of Water Affairs and Forestry, South Africa, 2004a, Inkomati Water Management Area: Internal Strategic Perspective - version 1, ed. Tlou and Matji (pty) Ltd. DWAF Report No P WMA 05/000/00/0303, DWAF, Pretoria.

Department of Water Affairs and Forestry, South Africa, 2004b, Olifants Water Management Areas Internal Strategic Perspective, ed. GMKS Tlou and Matji and WMB on behalf of the Directorate: National Water Resource Planning, DWAF Report No P WMA 04/000/00/0304, DWARF, Pretoria.

Department of Water Affairs and Forestry, South Africa, 2004c, Luvuvhu/Letaba Water Management Areas Internal Strategic Perspective, ed. Goba Moahloli Keeve Steyn (Pty) Ltd in association with Tlou and Matji, Golder Associates and BKS on behalf of the Directorate: National Water Resource Planning, DWAF Report No P WMA 02/000/00/0304, DWAF, Pretoria.

Department of Water Affairs and Forestry, South Africa, 2006, Letaba Catchment Reserve Determination Study - Main Report Final, ed. Howard and De Lange Inc., on behalf of the Directorate: Resource Directed Measures, DWAF Report No RDM/B800/00/CON/COMP/1304, DWAF, Pretoria. 


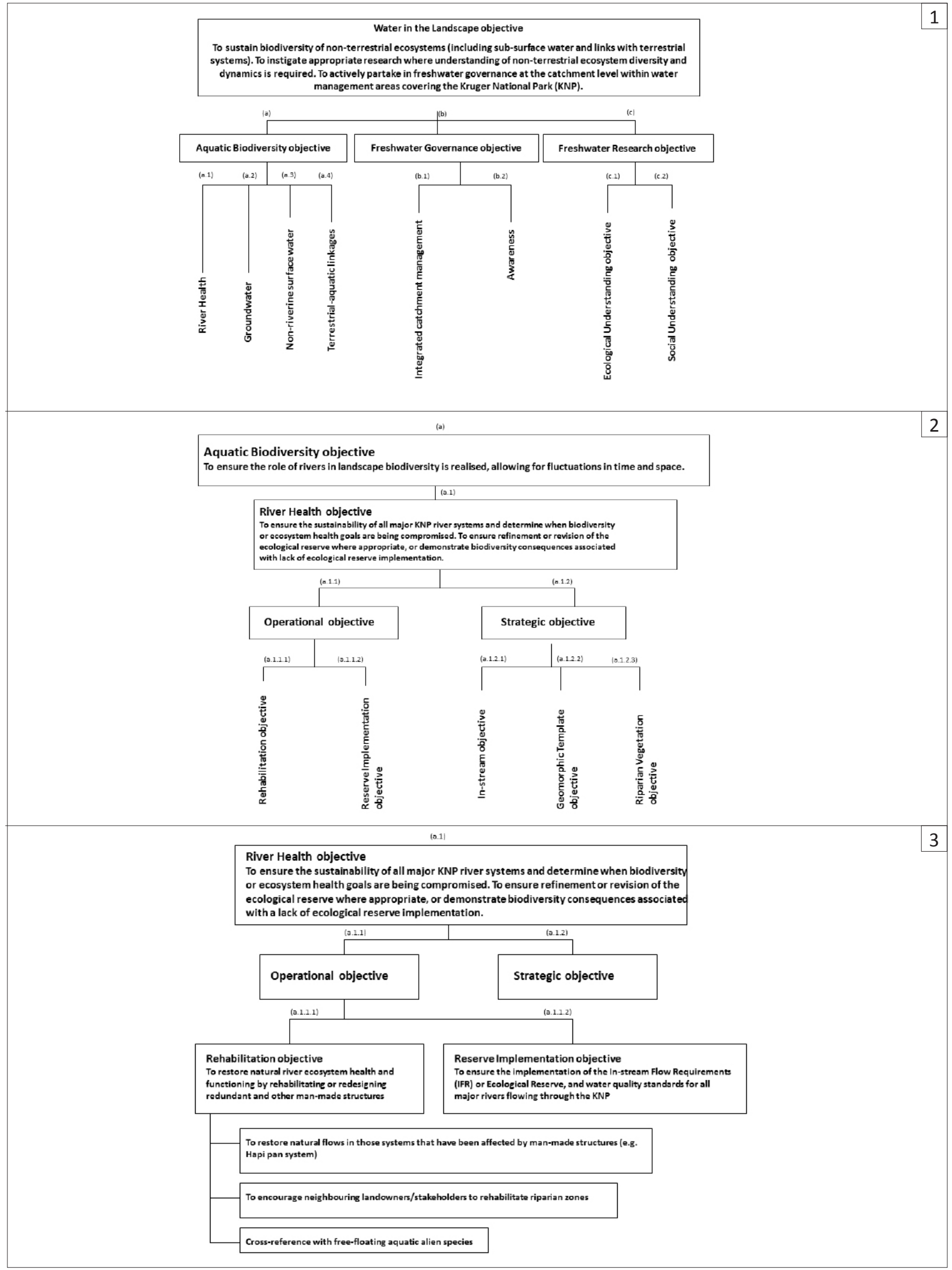




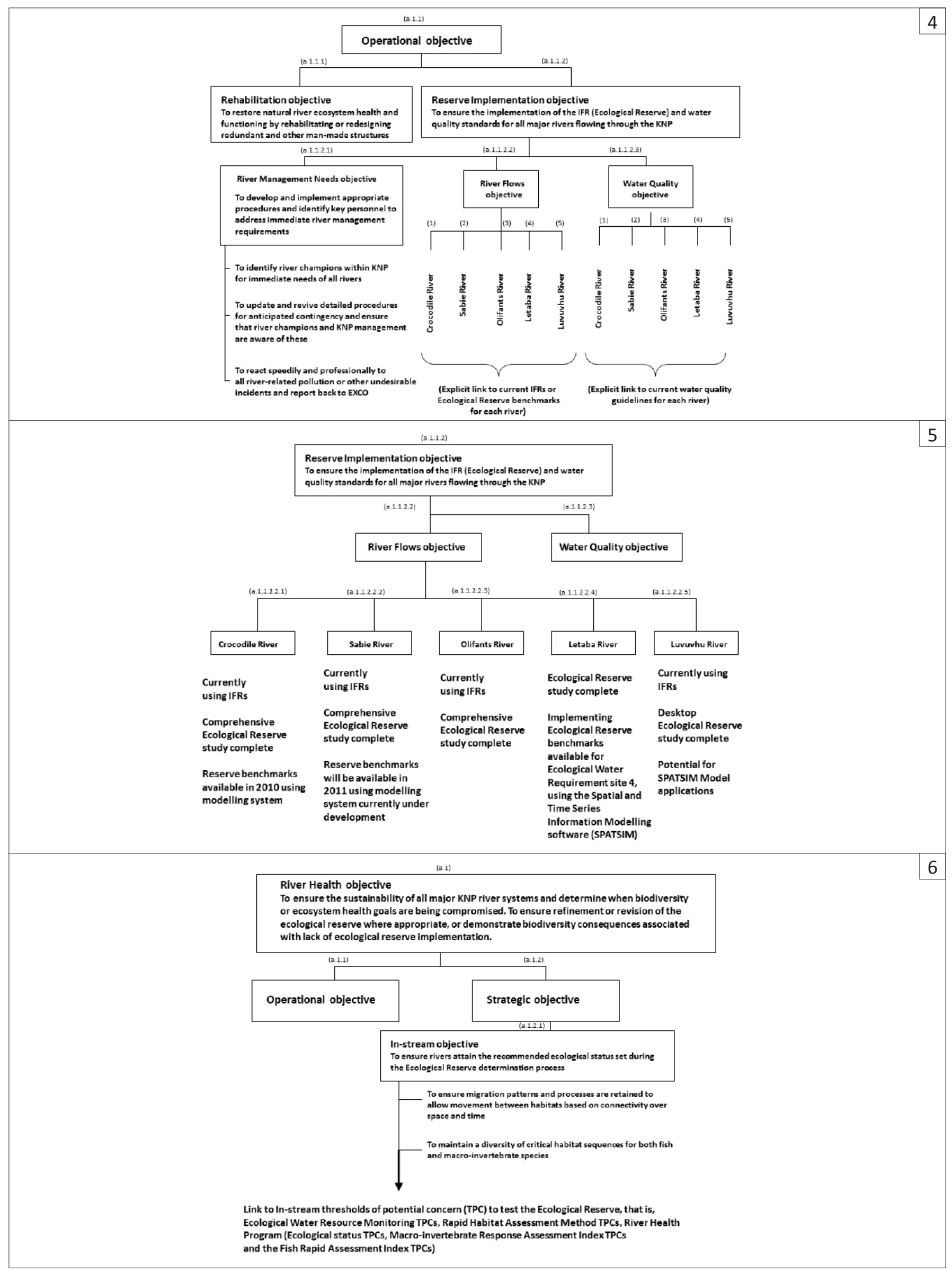




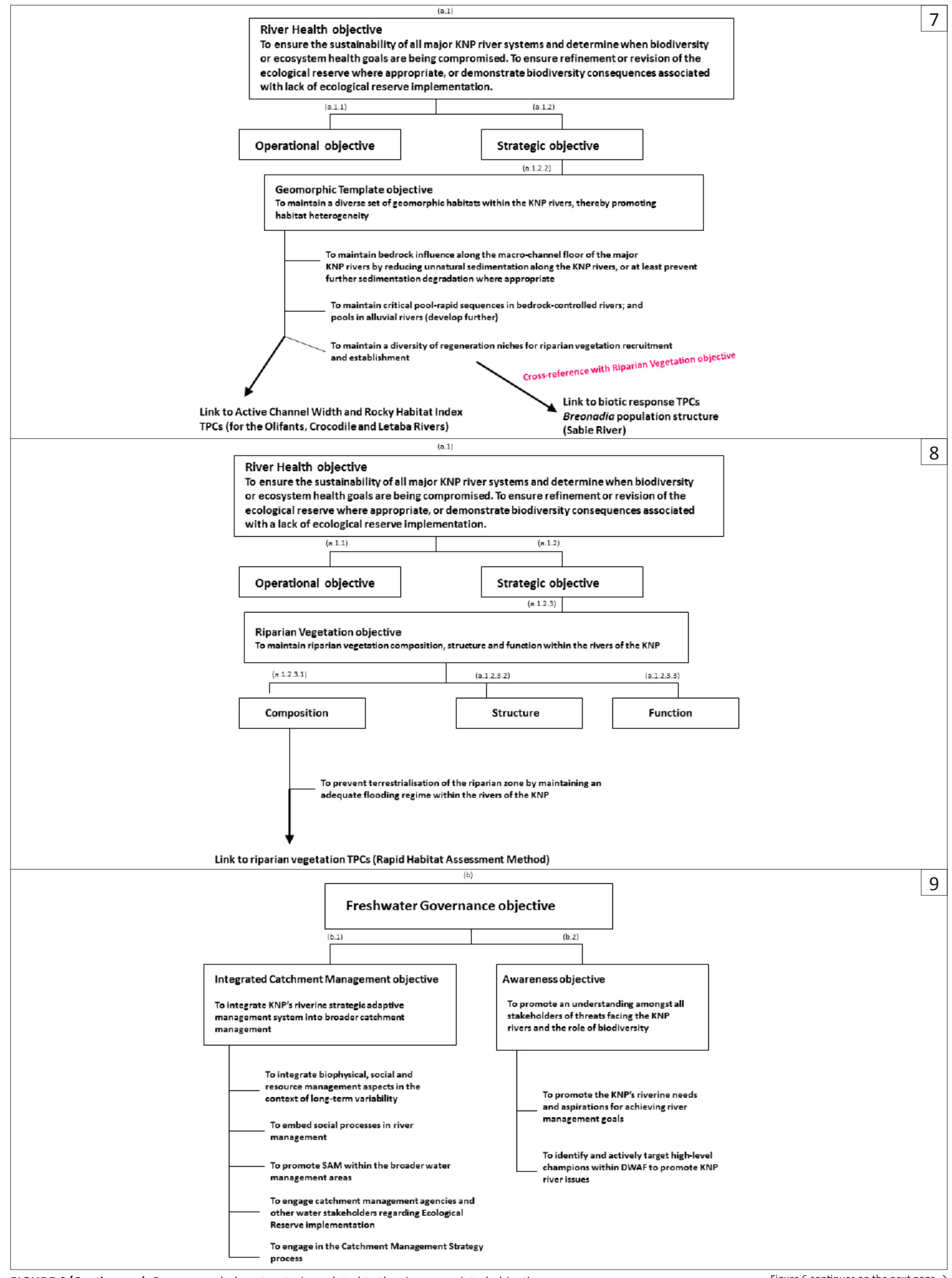




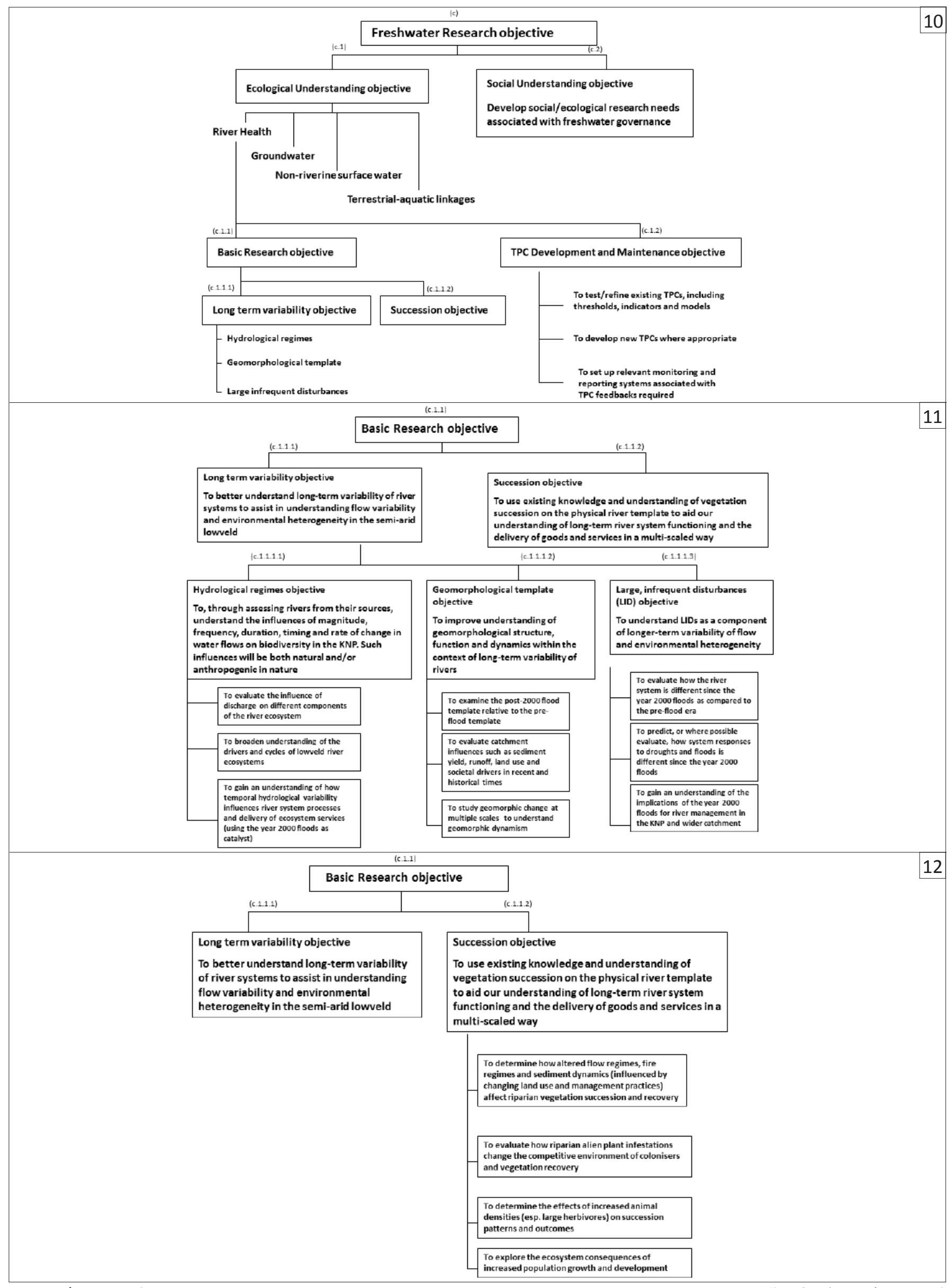




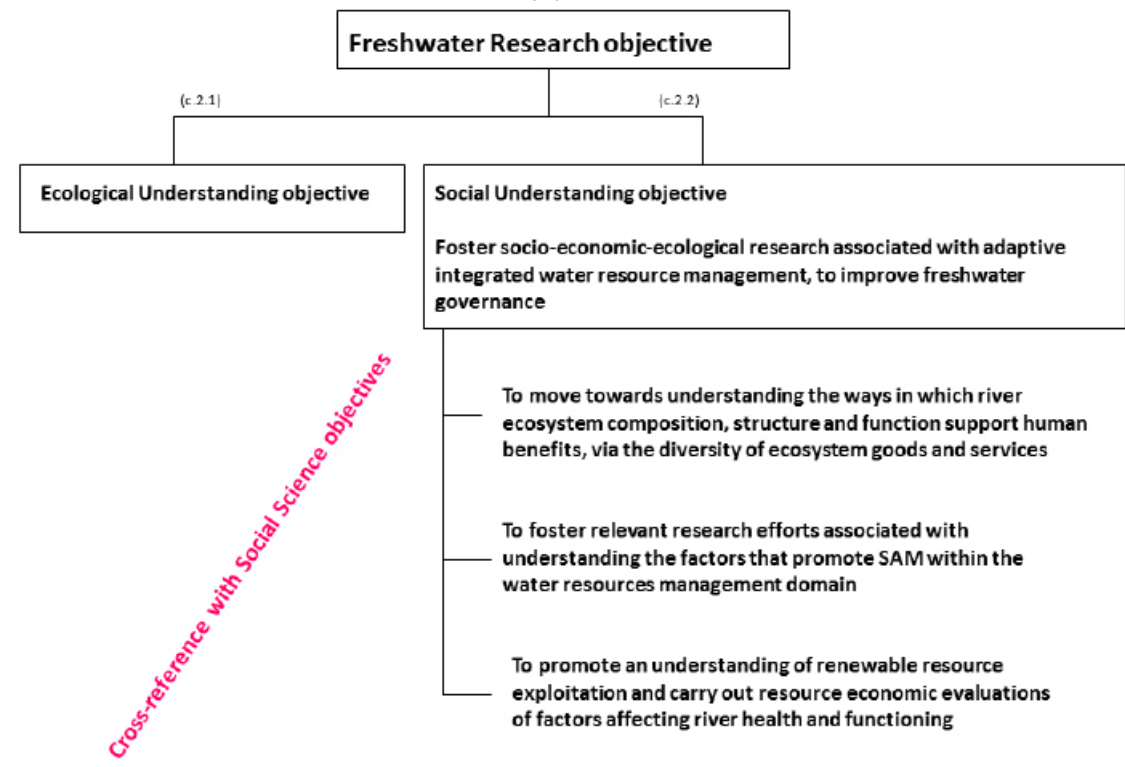

FIGURE 6 (Continues...): Recommended re-structuring related to the river-associated objectives.

TABLE 6: Status of the Ecological Reserve studies for major rivers of the Kruger National Park.

KNP river system Ecological reserve status

Crocodile River Intermediate reserve complete. Comprehensive reserve to be completed by February 2010.

Sabie River Intermediate reserve complete. Comprehensive reserve to be completed by February 2010.

Olifants River Comprehensive reserve completed in 2001. Updates of the reserve expected.

Letaba River Comprehensive reserve completed and approved in 2006.

Luvuvhu River Comprehensive reserve planned.

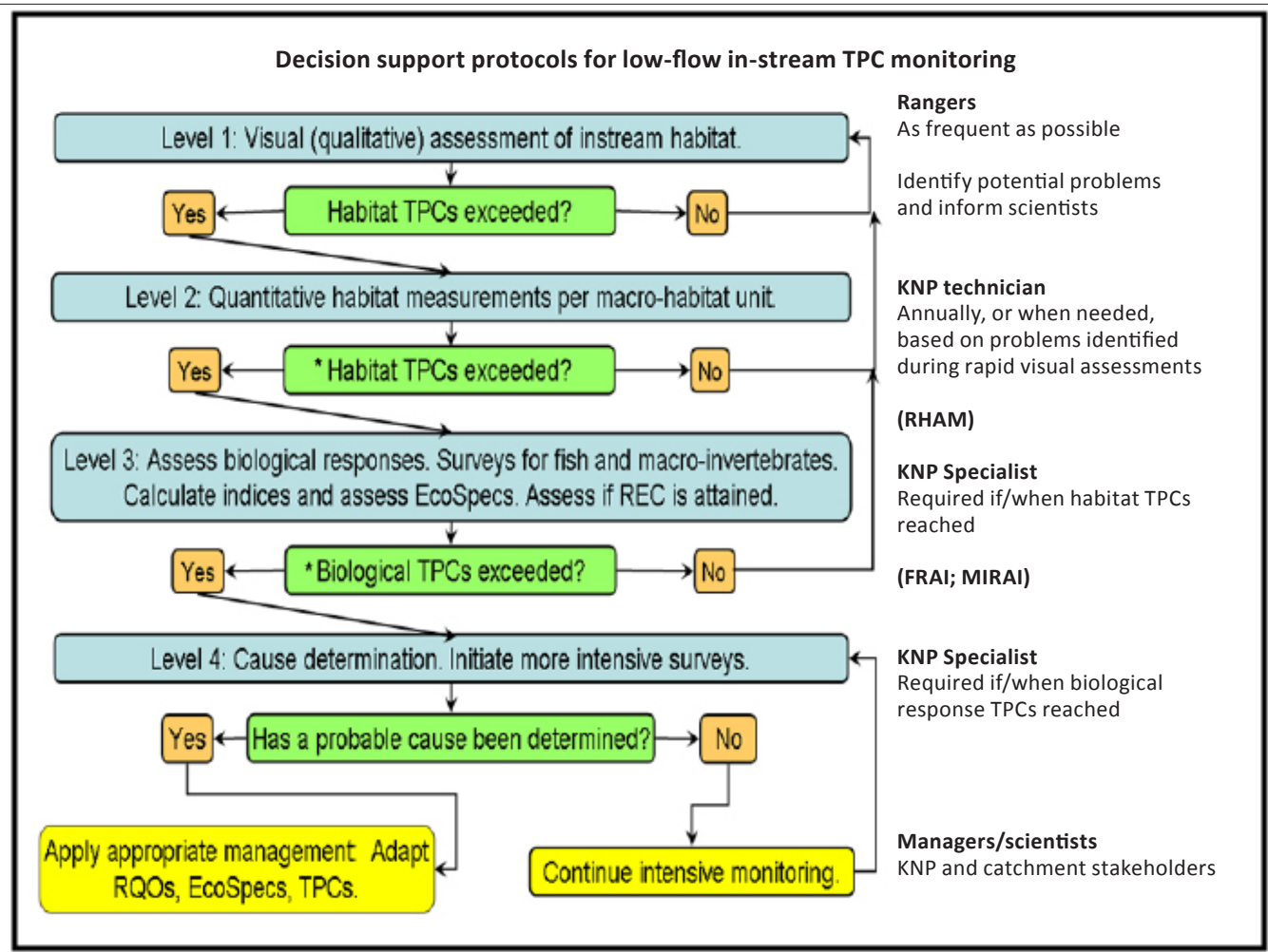

Source: Adapted from Kleynhans, C.J., Louw, M.D., Birkhead, A., Thirion, C., Deacon, A., Angliss, M., et al., 2009, 'On the way to Implementation: Ecological Reserve Monitoring', unpublished report.

REC, recommended ecological class; KNP, Kruger National Park; RHAM, Rapid Habitat Assessment Method; MIRAI, macro-invertebrate response assessment index; FRAI, fish rapid assessment index; RQOs, resource quality objectives; EcoSpecs, Ecological Specifications; TPC, threshold of potential concern.

*, TPCs, under development.

FIGURE 7: Envisaged structured decision-making framework to guide in-stream river biophysical monitoring and decision making associated with implementation of the Ecological Reserve. 
Department of Water Affairs and Forestry, South Africa, 2008a, National Aquatic Ecosystem Health Monitoring Programme (NAEHMP): River Health Programme (RHP) Implementation Manual. Version 2, DWAF, Pretoria.

Department of Water Affairs and Forestry, South Africa, 2008b, The Development of a Real-time Decision Support System (DSS) for the Crocodile East River System - Inception Report, ed. Clear Pure Water with Water for Africa and Dormehl Technology, on behalf of the Directorate: Water Resource Planning Systems, Project No WP 9429.

Department of Water Affairs, South Africa, 2009, Operationalise the Reserve: Rapid Habitat Assessment Model Manual, ed. D. Louw \& C.J. Kleyhans, Report No. RDM/Nat/00/CON/0709, DWAF, Pretoria.

Dickens, C.W.S. \& Graham, P.M., 2002, 'The South African Scouring System (SASS) Version 5 Rapid Assessment Method for Rivers', African Journal of Aquatic Science, 1-10.

Dowson, L., 2009, 'The effects of an extreme flood on Breonadia salicina population structure: Implications for modelling, monitoring and adaptive river management in the Kruger National Park', unpublished M. Sc. Dissertation, Animal, Plant and Environmental Studies, University of the Witwatersrand.

Foxcroft, L.C., 2009, 'Developing Thresholds of Potential Concern for invasive alien species: Hypotheses and concepts', Koedoe 51, 1-6. doi:10.4102/koedoe. v51i1.157

Gerber, A. \& Gabriel, M.J.M., 2002, Aquatic Invertebrates of South African Rivers: Field Guide, 1st edn., Resource Quality Services, Department of Water Affairs and Forestry, Pretoria.

Hellawell, J.M., 1978, Biological Surveillance of Rivers, Water Research Centre, Stevenage, UK.

Heritage, G.L., Van Niekerk, A.W. \& Moon, B.P., 1999, 'Geomorphology of the Sabie River, South Africa: an incised bedrock-influenced channel', in A.J. Miller \& A. Gupta (eds.), Varieties of Fluvial Forms, pp. 53-79, John Wiley and Sons, Chichester, UK.

Hughes, D.A., Mallory, S.J.L. \& Louw, D., 2008, Methods and Software for the Real-time Implementation of the Ecological Reserve - Explanations and User Manual, Water Research Commission Report No. 1582/1/08, Water Research Commission, Pretoria.

King, J. \& Louw, D., 1998, 'Instream flow assessments for regulated rivers in South Africa using the building-block methodology', Aquatic Ecosystem Health and Management 1, 109-124. doi:10.1080/14634989808656909, doi:10.1016/S1463-4988(98)00018-9

Kleynhans, C.J., 1999, 'The development of a fish index to assess the biological integrity of South African rivers', Water SA 25, 265-278.

Kleynhans, C.J., Louw, M.D., Thirion, C., Rossouw, N.J. \& Rowntree, K., 2005, River EcoClassification: Manual for EcoStatus determination (Version 1), Joint Water Research Commission and Department of Water Affairs and Forestry report, WRC Report No. KV 168/05, WRC, Pretoria.

Kleynhans, C.J., 2007, Module D: Fish Response Assessment Index in River EcoClassification: Manual for EcoStatus Determination (version 2), Joint Water Research Commission and Department of Water Affairs and Forestry report, WRC Report No. TT 330/08, WRC, Pretoria.

Kleynhans, C.J., Louw, M.D., Birkhead, A., Thirion, C., Deacon, A., Angliss, M., et al., 2009, 'On the way to Implementation: Ecological Reserve Monitoring', unpublished report.

Kruger National Park, 1989, 'Kruger National Park water provision policy', unpublished report.

Kühn, A.L., 1991, 'Sensitiewe visspesie werkswinkel 1991' [Sensitive fish species workshop 1991], Rivers Research Programme Report, Kruger Nationale Park.

Louw, D. \& O'Keeffe, J., 1999, Luvuvhu River IFR: Second Refinement, Institute for Water Research, Grahamstown. Place of publisher.

Mackenzie, J.A., Van Coller, A.L. \& Rogers, K.H., 1999, Rule Based Modelling for Management of Riparian Systems, Water Research Commission Report No. 813/1/99, WRC, Pretoria.

Mackenzie, J.A., Jacoby, D.L. \& Rogers, K.H., 2003, Modelling of Terrestrialisation and Technology Transfer to Enable Management of Kruger National Park Rivers, Water Research Commission Report No. 1063/1/03, WRC, Pretoria.

McLoughlin, C.A., 2009, Status and progress with the framework for prototyping catchment level adaptive management processes within the Inkomati, Olifants and Letaba-Luvuvhu Water Management Areas, unpublished Water Research Commission report.

McLoughlin, C.A., Deacon, A. \& Sithole, H., 2009a, 'Implementation status of river TPCs developed and tested within the Kruger National Park, including TPC audits achieved', unpublished Water Research Commission report.

McLoughlin, C.A., Mackenzie, J., Rountree, M., Deacon, A. \& Sithole, H., 2009b, 'Update on Kruger National Park River TPCs - Roll-out of the Geomorphology and in-stream TPC monitoring and data collection associated with the Terrestrialisation and Breonadia TPCs', unpublished Water Research Commission report.

McLoughlin, C.A. \& Mackenzie, J., 2010, 'Update on new developments associated with riparian vegetation TPC requirements for the Kruger National Park', unpublished Water Research Commission report.
Moore, C.A. \& Chutter, F.M., 1988, A survey of the conservation status and benthic biota of the major rivers of the Kruger National Park, Council for Scientific and Industrial Research, National Institute for Water Research, Pretoria.

O'Keeffe, J. \& Rogers, K.H., 2003, 'Heterogeneity and management of the Lowveld rivers', in J.T.D Toit, K.H. Rogers \& H.C. Biggs (eds.), The Kruger Experience: Ecology and Management of Savanna Heterogeneity, pp. 447-468, Island Press, Washington.

Pickett, S.T.A., Parker, V.T. \& Fiedler, P.L., 1992, 'The new paradigm in ecology: Implications for conservation biology above the species level', in P.L. Fiedler \& S.K. Jain (eds.), Conservation Biology: The Theory and Practice of Nature Conservation, Preservation and Management, pp. 65-88, Chapman and Hall, New York.

Pickett, S.T.A., Cadenasso, M.L. \& Benning, T.L., 2003, 'Biotic and abiotic variability as key determinants of savanna heterogeneity at multiple spatiotemporal scales', in J.T. du Toit, K.H. Rogers \& H.C. Biggs (eds.), The Kruger experience: ecology and management of savanna heterogeneity, pp. 22-40, Island Press, ecology and
Washington.

Pienaar, U., 1961, 'A supplementary checklist of Decapoda, freshwater fish, amphibians, reptiles and and small mammals recorded in the Kruger National Park', Koedoe 4, 167-177.

Poff, N.J., Allan, J.D., Bain, M.B., Karr, J.R., Prestegaard, K.I., Richter, D.B., Sparks, R.E. \& Stromberg, J.C., 1997, 'The natural flow regime: a paradigm for river conservation and restoration', BioScience 47, 769-784. doi:10.2307/1313099

Pollard, S. \& Du Toit, D., in review, Towards the sustainability of freshwater systems in South Africa: An exploration of factors that enable and constrain meeting the ecological reserve within the context of Integrated Water Resource Management in the catchments of the lowveld, Water Research Commission Report, WRC, Pretoria.

Rogers, K.H., 1997, 'Operationalizing ecology under a new paradigm: An African perspective', in S.T.A. Pickett, R.S. Ostfeld, M. Shachak \& G.E. Likens (eds.), The Ecological Basis of Conservation. Heterogeneity, Ecosystems and Biodiversity, pp. 257-270, Chapman and Hall, New York.

Rogers, K.H., 2003, 'Adopting a heterogeneity paradigm: Implications for management of protected areas', in J.T. du Toit, K.H. Rogers \& H.C. Biggs (eds.), The Kruger Experience: Ecology and Management of Savanna Heterogeneity, pp. 41-58, Island Press, Washington.

Rogers, K.H. \& Bestbier, R., 1997, Development of a Protocol for the Definition of the Desired State of Riverine Systems in South Africa, Department of Environmental Affairs and Tourism, Pretoria.

Rogers, K.H. \& Biggs, H., 1999, 'Integrating indicators, end points and value systems in the strategic management of the rivers of the Kruger National Park', Freshwater Biology 41, 439-451. doi:10.1046/j.1365-2427.1999.00441.x

Rogers, K.H. \& O'Keeffe, J., 2003, 'River heterogeneity: Ecosystem structure, function, and management', in J.T. du Toit, K.H. Rogers \& H.C. Biggs (eds.), The Kruger Experience: Ecology and Management of Savanna Heterogeneity, pp. 189-218, Island Press, Washington.

Rountree, M.W., Rogers, K.H. \& Heritage, G.L., 2000, 'Landscape state change in the Semi-arid Sabie River, Kruger National Park, in response to flood and drought', Southern African Geographical Journal 82, 173-181.

Rountree, M.W. \& Rogers, K.H., 2004, 'Channel pattern changes in the mixed bedrock/alluvial Sabie river, South Africa: response to and recovery from large infrequent floods', in D.G. de Jalon \& P. Vizcaino (eds.), Proceedings of the Fifth International Symposium on Ecohydraulics, pp. 318-324, IAHR, Madrid, Spain.

Rountree, M., McLoughlin, C.A. \& Deacon, A., 2008, 'Integrating the NAEHMP monitoring data with the KNP Strategic Adaptive Management System: TPC refinement for rivers', unpublished Water Research Commission report.

Rountree, M., McLoughlin, C.A., Mackenzie, J., Deacon, A. \& Sithole, H., 2008, 'Kruger National Park TPC data collection, testing and implementation', unpublished Water Research Commission report.

Russell, I.S., 1997, 'Monitoring the conservation status and diversity of fish assemblages in the major rivers of the Kruger National Park', unpublished Ph.D. thesis, Zoology Department, University of the Witwatersrand.

Sanders, T.G. \& Ward, R.C., 1993, 'Water quality monitoring system design, simplified, pollution prevention', Journal of Water and Wastewater International 8, 44-49.

Stankey, G.H., Clark, R.N. \& Bormann, B.T., 2005, Adaptive management of natural resources: theory, concepts and management institutions, Gen. Tech. Rep. PNW-GTR-654, US Department of Agriculture, Forest Service, Pacific Northwest Research Station, Portland, OR.

Tharme, R., 1997, Sabie-Sand River System: In-stream Flow Requirements. Proceedings of the IFR workshop, Report to the Department of Water Affairs and Forestry, Southern Waters Ecological Research and Consulting cc, Freshwater research unit, University of Cape Town, Rondebosch.

Van Coller, A.L., 1993, 'Riparian vegetation of the Sabie River: relating spatial distribution patterns to characteristics of the physical environment', unpublished M.Sc. Dissertation, Centre for Water in the Environment, University of the Witwatersrand. 
Van Coller, A.L., Rogers, K.H. \& Heritage, G.L., 1997, 'Linking riparian vegetation types and fluvial geomorphology along the Sabie River within the Kruger National Park, South Africa', African Journal of Ecology 35, 194-212. doi:10.1111/j.1365-2028.1997.090-89090.x

Van Coller, A.L., Rogers, K.H. \& Heritage, G.L., 2000, 'Riparian vegetationenvironment relationships: Complimentarity of gradients versus patch hierarchy approaches', Journal of Vegetation Science 11, 337-350. doi:10.2307/3236626
Van Niekerk, A.W., Heritage, G.L. \& Moon, B.P., 1995, 'River classification for management: the geomorphology of the Sabie River in the eastern Transvaal', Southern African Geographical Journal 77, 68-76.

Weeks, D.C., O'Keeffe, J.O., Fourie, A. \& Davies, B.R., 1996, The ecological status of the Sabie-Sand River system. Volume 1: A pre-impoundment study of the Sabie-Sand River system, Eastern Transvaal with special references to predicted impacts on the Kruger National Park, Water Research Commission Report, WRC, Pretoria.

\section{Appendix 1}

Audit report format used within the thresholds of potential concern (TPC) tabling process within the Kruger National Park strategic adaptive management (SAM) system. Example: Breonadia TPC exceedances

\section{Conservation services management committee meeting, Kruger National Park}

Notification of river TPC reached

Breonadia salicina population structure in the Sabie River, first TPC assessment

\section{Background}

The loss of bedrock influence in the Kruger National Park (KNP) river systems is associated with increasing sediment storage - from an increased sediment supply and/or reduced stream-flow ability to transport sediment. The result is a loss of bedrock habitats, because of the smothering of exposed rock by sediment, with a consequent reduction in available regeneration niches for various riparian tree species, leading to a decrease in riparian vegetation diversity. A useful indicator of this loss in bedrock influence is the population structure of the tree species Breonadia salicina, because it grows in close proximity to the active channel and in close association with bedrock habitats (Van Coller 1993). B. salicina is a good indicator of the change in sediment regime and/or flow because although it can germinate abundantly on any substrate type, it establishes only on exposed bedrock; this allows for sufficient anchorage during high flow events, thus increasing chances of individual survival and persistence.

Importantly, current knowledge suggests that the $B$. salicina population displays a negative, J-shaped curve on geomorphic units with large amounts of bedrock influence (see Figure 1) (De Fonteine, unpublished; Mackenzie, Van Coller \& Rogers 1999). The negatively skewed J-shaped curve represents a population where the abundance of Breonadia individuals is highest in the smaller size classes, and diminishes as the size class increases (Mackenzie, Van Coller \& Rogers 1999). This population structure results if there is (1) sufficient exposed bedrock for establishment of seedlings, including a suitable flow regime, (2) continuous, rather than punctuated, recruitment and (3) an increasing rate of mortality within cohorts because of high disturbance rates. Changes to the

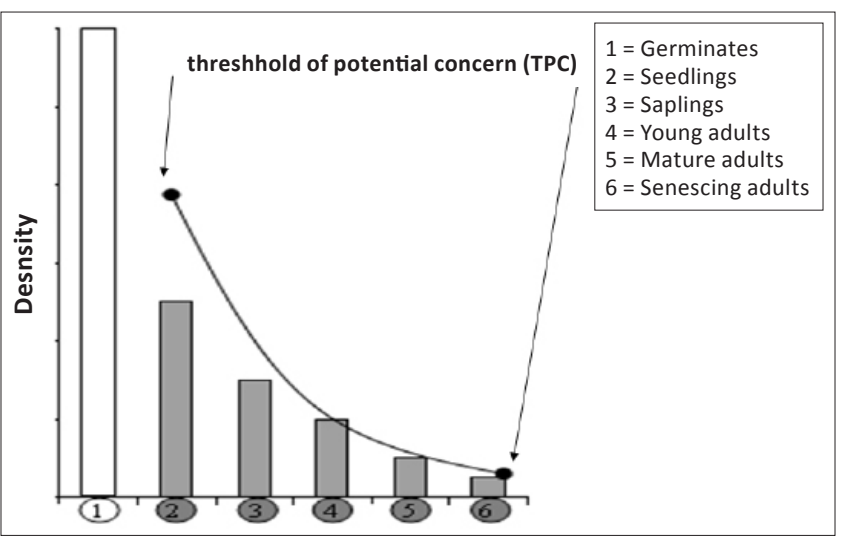

Source: Mackenzie, J.A., Van Coller, A.L. \& Rogers, K.H., 1999, Rule Based Modelling for Management of Riparian Systems, Water Research Commission Report No. 813/1/99, WRC, Pretoria.

Breonadia salicina population size class 1 (Germinates) is not utilised in TPC auditing.

FIGURE 1: The negative, J-shape population structure for all non-germinant, established individuals of Breonadia salicina, used for the auditing of thresholds of potential concern.

negative, J-shape population structure exhibited by B. salicina will occur if there is increased sedimentation during the establishment phase of its lifecycle.

\section{Definition of the threshold of potential concern}

Ultimately, a loss of bedrock influence via sedimentation, and/or a sharp reduction in flow frequency will cause a reduction in seedling recruitment of $B$. salicina, resulting in the loss of the negative, J-shaped population structure (Mackenzie et al. 1999). Figure 2 shows in concept the rippleeffect changes that would occur in the population structure, following a marked increase in sediment storage and/or a reduction in flow frequency over time (Mackenzie et al. 1999). An $8 \%$ level of bedrock proportion in Pool-rapid channel types was considered by Mackenzie et al. (1999) as a rough guide to critically low levels of bedrock in the river, and was considered a level of concern.

Characteristics of the negative, J-shaped curve, fitted to the population structure of all non-germinant size classes of $B$. salinica monitored in the field, are used for TPC auditing. Assessment of the TPC is carried out using the log of this curve, because the log of a negative, J- shaped curve outputs a straight line, and pertinent parameters can then be assigned to this line for monitoring change in the population structure. 
The values given in Figure 3 represent the lower limits (thresholds) of the parameters associated with the logged, negative, J-shaped population structure curve of $B$. salicina (i.e. a straight line), derived from modelled populations where bedrock proportion was at $8 \%$ cover. It is important to note that these are first estimates and need refinement over time within the strategic adaptive management (SAM) system.

\section{Data or information supporting the threshold of potential concern}

The Breonadia TPC was developed by Mackenzie et al. (1999) during the KNP River Research Programme, using information collected within belt transects demarcated for research along the length of the Sabie River. Field data were used to estimate levels of concern for the degree of bedrock within critical sites along the Sabie River.

The current assessment of the Breonadia TPC was completed using data sampled during August-September 2008 at dedicated monitoring sites along the Sabie River. Reestablishment of monitoring sites along the Sabie River for the Breonadia TPC was carried out as part of the Water Research Commission-funded 'Adaptive Management' project. All individuals recorded were categorised into size classes, and size class frequencies were established in order to assess the TPC parameters associated with the B. salicina sub-populations occurring at each site. These parameters were compared against the TPC thresholds given above.

\section{Results}

Interpretation of the results from the Breonadia TPC audits undertaken in 2008 for the three monitoring sites along the Sabie River (Figure 4) indicated that all the TPC parameters associated with $B$. salicina population structure within each site have been exceeded.

\section{Consequences or potential impacts}

A loss of bedrock influence along the riparian corridors of the KNP results in diminished habitat diversity within the rivers. Consequently, this leads to a decrease in regeneration niches for certain riparian vegetation within the KNP, and a loss of riparian vegetation diversity. This is in contradiction to the mandate of the KNP - that of maintaining biodiversity.

However, the large flood of 2000 impacted greatly on the $B$. salicina population within the Sabie River, causing thresholds to be exceeded naturally. The populations are still recovering, but the question arises as to when the population will recover for re-use within the TPC.

Understanding prior to the 2000 flood had suggested that the B. salicina sub-populations would recover within 4 years after such a large flood event occurred. However, a


Source: Mackenzie, J.A., Van Coller, A.L. \& Rogers, K.H., 1999, Rule Based Modelling for Management of Riparian Systems, Water Research Commission Report No. 813/1/99, WRC, Pretoria. This example follows a large increase in sedimentation, and reduced flow frequency, leading to a loss in bedrock influence.

(a) to (d), change over time.

Breonadia salicina population size class 1 (Germinates) is not utilised in TPC auditing.

FIGURE 2: A hypothesis of the change over time in population size structure of non-germinant individuals of Breonadia salicina on bedrock-dominated channel sections. 


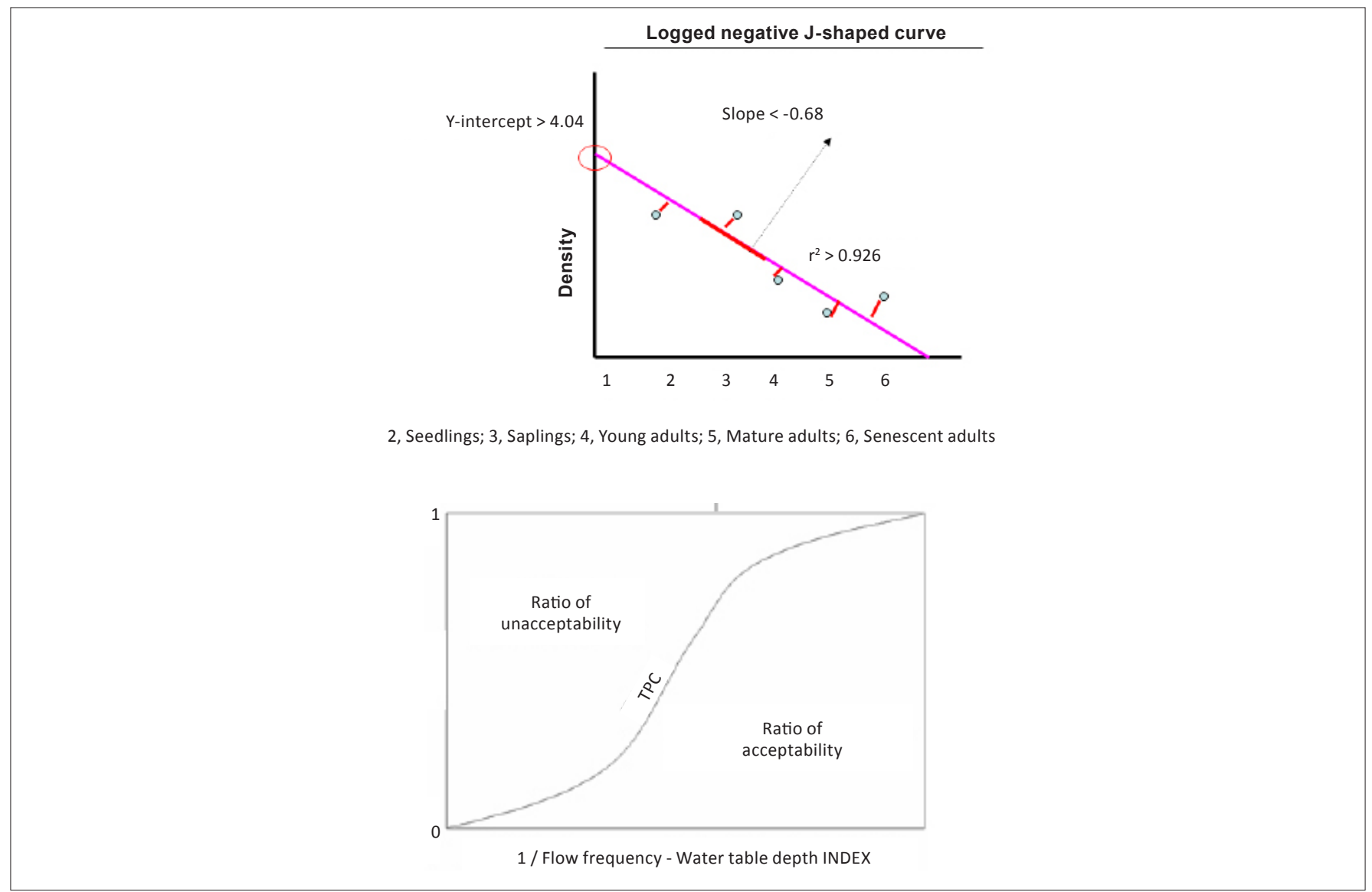

Breonadia salicina population size class 1 (Germinates) is not utilised in auditing TPC.

FIGURE 3: Parameters for the Breonadia threshold of potential concern (TPC).

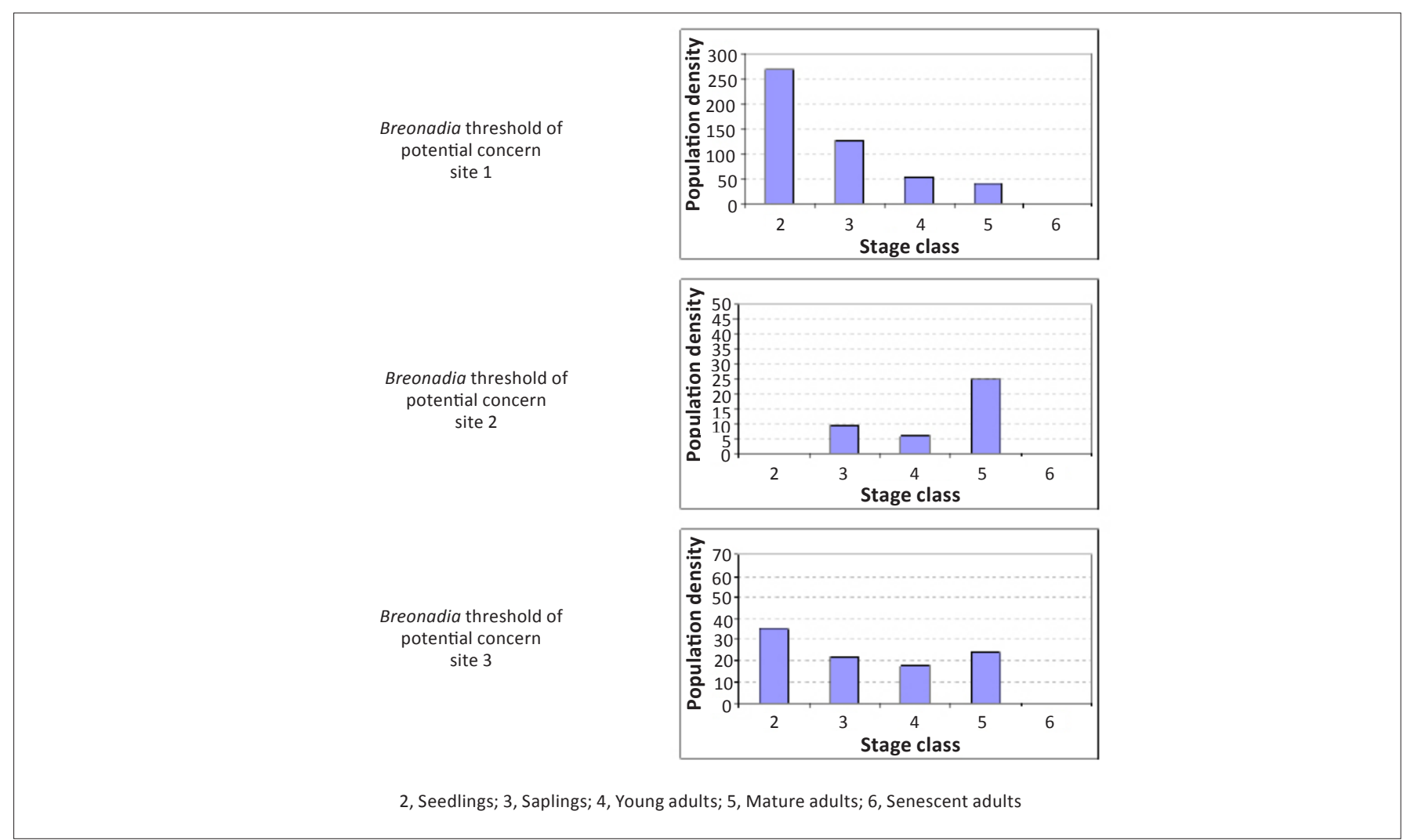

Breonadia salicina population size class 1 (Germinates) is not utilised in TPC auditing for each site, all TPC parameters are exceeded.

FIGURE 4: Breonadia salicina population structure at the three threshold of potential concern (TPC) monitoring sites along the Sabie River. 
research project conducted in 2004 by the Centre for Water in the Environment at the University of the Witwatersrand showed that B. salicina sub-populations did not recover as expected. Evidence found during this study indicated that the surviving adult $B$. salicina individuals put more resources into sprouting as a means of regeneration, than flowering and setting of seed. Consequently, a smaller seed source results in fewer germinants, and less recruitment into the seedling stage class, with a subsequent loss in the negative, J-shape of the population structure.

Refined understanding during this research predicted that the $B$. salicina population would recover 8 years after a large flood event. The B. salicina monitoring data collected in 2008 contradicted this prediction, although there is increasing evidence to suggest that the adults have started to flower and set seed.

\section{Proposed management action}

- The next action to be taken should be to re-sample the B. salicina population during 2009 within the monitoring sites demarcated along the Sabie River, to investigate the potential rate of population recovery, for example, increased flowering, germination and numbers of seedlings.

- Further work is being undertaken as part of the Water Research Commission funded 'Adaptive Management' project to test and refine this TPC, including monitoring site selection and the population modelling component.

\section{References}

Mackenzie, J.A., Van Coller, A.L. \& Rogers, K.H., 1999, Rule Based Modelling for Management of Riparian Systems, Water Research Commission Report No. 813/1/99, WRC, Pretoria.

Van Coller, A.L., 1993, 'Riparian vegetation of the Sabie River: Relating spatial distribution patterns to the physical environment', MSc thesis, Centre for Water in the Environment, University of the Witwatersrand. 